\title{
A reconnaissance study in Izmir (Bornova Plain) affected by October 30, 2020 Samos earthquake
}

\author{
Ayhan Nuhoğlu ${ }^{a}$, Mehmet Fahrettin Erener ${ }^{\mathrm{b}}$, Çă̆layan Hızal ${ }^{\mathrm{c}, *}$, Cem Kıncal ${ }^{\mathrm{d}}$, \\ Devrim Şüfa Erdoğan ${ }^{a}$, Özkan Cevdet Özdağ ${ }^{\mathrm{e}}$, Mustafa Akgün ${ }^{\mathrm{f}}$, Emre Ercan ${ }^{\mathrm{a}}$, Emre Kalfa ${ }^{\mathrm{b}}$, \\ Duygu Köksal $^{g}$, Yaprak İpek ${ }^{g}$, Alper Sezer ${ }^{a}$ \\ ${ }^{a}$ Ege University, Department of Civil Engineering, Bornova, Izmir, Turkey \\ ${ }^{\mathrm{b}}$ Ege University, The Graduate School of Natural and Applied Sciences, Bornova, Izmir, Turkey \\ ${ }^{\mathrm{c}}$ Izmir Institute of Technology, Department of Civil Engineering, Urla, Izmir, Turkey \\ ${ }^{\mathrm{d}}$ Dokuz Eylul University, Department of Geological Engineering, Buca, Izmir, Turkey \\ ${ }^{\mathrm{e}}$ Dokuz Eylul University, Earthquake Research and Implementation Center, Buca, Izmir, Turkey \\ ${ }^{\mathrm{f}}$ Dokuz Eylul University, Department of Geophysical Engineering, Buca, Izmir, Turkey \\ ${ }^{\mathrm{g}}$ Dokuz Eylul University, The Graduate School of Natural and Applied Sciences, Buca, Izmir, Turkey
}

\section{A R T I C L E I N F O}

\section{Keywords:}

Samos earthquake

Damage assessment

Izmir (Bornova plain)

Soil response

Local site effects

Spectral characteristics

\begin{abstract}
A B S T R A T
On October 30th of 2020, 14:51 (GMT+3:00), Izmir city was hit by an earthquake of $\mathrm{M}_{\mathrm{w}}=7.0$ magnitude (according to USGS). A rupture of 30-40 km of a west-east normal fault, which is roughly $12 \mathrm{~km}$ north to Samos Island caused significant damage, particularly in Izmir (Bornova plain). This study aims to present the preliminary field investigations, evaluation of structural damage as well as the possible geotechnical phenomenon affecting the damage that occurred. In this context, an extensive analysis of spectral characteristics of the earthquake and local site effects is presented. Field investigations reveal that there is a significant amplification of the rock acceleration along with a basin effect in the region, which results in a wider constant acceleration region. In addition, analysis of earthquake records shows a remarkable level of soil nonlinearity. Considering all these aspects, a detailed assessment of structural damage observed in Izmir Bayrakli District is presented. It is evident that, structures of poor construction details behaved as if they were affected by a near field earthquake. The structures to be constructed in alluvial zones such as Manavkuyu neighborhood should be designed considering the effects of soil amplification including basin effects and soil nonlinearity. To fulfill this aim, comparative results of $1 \mathrm{D} / 2 \mathrm{D} / 3 \mathrm{D}$ ground response analyses should be performed, for revising current earthquake codes.
\end{abstract}

\section{Introduction}

On October 30th of 2020, 14:51 (GMT+3:00), Izmir, Turkey's $3^{\text {rd }}$ biggest city of more than 4 million population was hit by an earthquake of $\mathrm{M}_{\mathrm{w}}=7.0$ according to USGS [1]. The epicentre of the earthquake is the north of Samos Island of Greece, which is also close to shoreline of Seferihisar municipality of Izmir (Fig. 1). Various organisations reported the magnitude of the earthquake ranging between 6.6 and 7.2. In this regard, Ministry of Interior Disaster and Emergency Management Presidency-AFAD, Kandilli Observatory and Earthquake Research Institute-KOERI, GeoForschungs Zentrum, Helmholtz-Zentrum Postdam Deutsches-GFZ and Observatoire de la Côte d'Azur- OCA declared that the moment magnitude of earthquake is 6.6, 6.9, 7.0, 7.2 and the depths were $16 \mathrm{~km}, 10 \mathrm{~km}, 15 \mathrm{~km}$ and $10 \mathrm{~km}$, respectively [2]. The main shock of $0.11 \mathrm{~g}$ surface peak ground acceleration (NS direction - observed at 3513 Bayraklı station) was accompanied by more than 5000 aftershocks of lower magnitude, which were still being recorded in December 2020.

In fact, the megacity is surrounded by fourteen active fault zones, which may trigger one another's activity [3]. Ground motion simulations reveal that the city can be exposed up to a $0.4 \mathrm{~g}$ surface peak ground acceleration for a 475-year return period [4-7]. Izmir metropolitan city is under the threat of many seismogenic zones, and non-instrumental period records going back to 17 B.C. reveal that an earthquake of an intensity of $\mathrm{X}$ and an estimated magnitude of 7.0 has

\footnotetext{
* Corresponding author.

E-mail address: caglayanhizal@iyte.edu.tr (Ç. Hızal).
} 


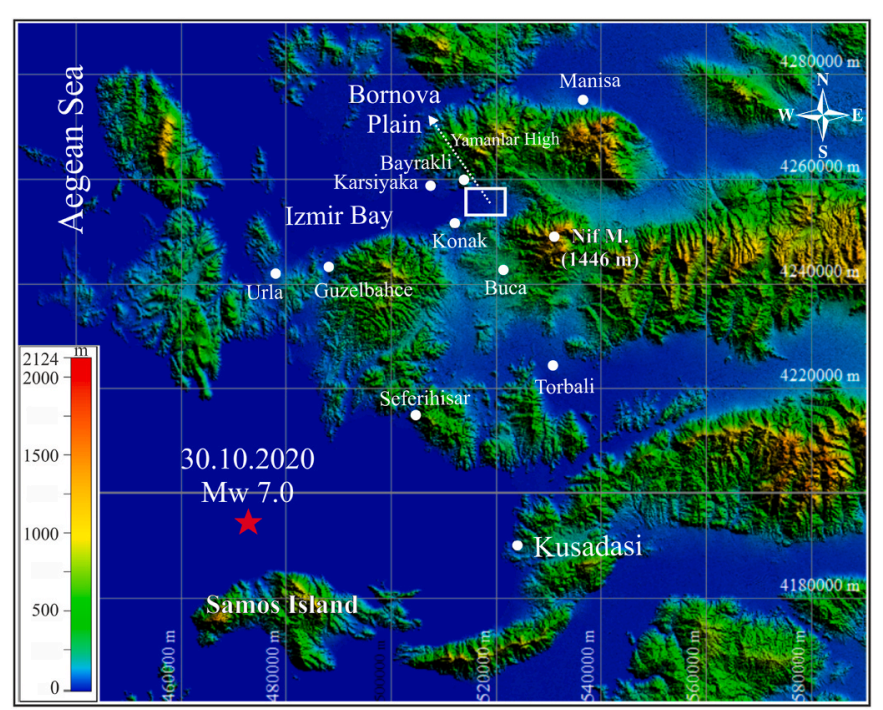

Fig. 1. Location map of main shock and the investigation area (Bornova Plain).

destroyed 13 Ionian cities, including Ephesus [8]. More than twenty records until November 1883 is constituted of observations denoting very high intensity, total collapse of cities, fires, increased amount of damage in valleys of Gediz and Menderes rivers, ports, casualties up to 20000 (which is significant in comparison with population of Izmir and its vicinity) as well as tsunami formation. In the instrumental period, from 1900 to today, eight earthquakes of magnitudes greater than 6.0 was recorded, among these, 1928 Torbalı and 1930 Dikili earthquakes caused collapse of about 2000 and 1000 houses, respectively.

Since Izmir and its periphery is within a highly active seismic zone, and the last earthquake causing mass destruction occurred almost 250 years ago, several zonation attempts in terms of ground shaking and liquefaction susceptibility were performed. RADIUS project, performed by Erdik et al. [9] is a good compilation of the seismic threat in Izmir and its periphery. The study provides a microzonation study based on the Standard Penetration Test (SPT), Cone Penetration Test (CPT) and Field Vane Test data, and soils are classified according to Turkish Earthquake Code 1998 (Regulations for the Structures Built in Disaster Areas) [10]. Microzonation maps based on average upper $30 \mathrm{~m}$ shear wave velocity, soil class, liquefaction susceptibility and soil amplification were prepared. Later, a detailed Ph.D. thesis by Kuruoğlu [11] provided the local responses of northern and eastern Izmir soils by use of 1D soil response analyses, the results of which were mapped using a Geographical Information Systems (GIS) software. The study also provides maps of liquefaction susceptibility and post-liquefaction settlements. To update the RADIUS project, the TUBITAK 1007 KAMAG project $106 \mathrm{G} 159$ was carried out between 2007 and 2012. Within the scope of this project, microzonation studies (microtremor, multi-channel analysis of surface waves (MASW), ground penetrating radar (GPR), microgravity, electrical resistivity tomography (ERT), etc.) were carried out for Izmir province with a sampling interval of $1 \mathrm{~km}$. Possible dynamic behaviour of the soil was investigated by obtaining parameters such as $\mathrm{V}_{\mathrm{s}, 30}$ (average shear wave velocity in upper $30 \mathrm{~m}$ ), $\mathrm{T}_{0}$ (predominant period), $A_{\max }$ (maximum amplification), etc. [12]. Later, Altun et al. [13] performed a microzonation study considering the northern coasts of Izmir. By use of a large database, the authors performed 1D soil response analyses with equivalent linear method, for mapping soil amplification, surface accelerations as well as ground shaking intensity, under a scenario earthquake of $\mathrm{M}_{\mathrm{w}}=6.9$ magnitude. The data was previously used for mapping the liquefaction susceptibility of northern coasts [14]. Literature also includes several attempts for evaluation of the $\mathrm{H} / \mathrm{V}$ spectral ratio (i.e. the ratio between the Fourier amplitude spectra of the horizontal and the vertical component of microtremors) behaviour of
Izmir [15-19].

Assessment of post-earthquake situations has a crucial importance during the decision-making and risk analysis procedures aftermath such disasters [20]. In this context, this multidisciplinary research aims at presenting the results of a reconnaissance study in Bornova Plain performed after the 2020 Samos earthquake to reveal the first impression regarding the structural damages associated with the local site effects. For this purpose, scientists from three departments, namely, civil, geological and geophysical engineering attended a comprehensive field survey and post-earthquake assessment procedure for this reconnaissance study. Observations on aftermath of earthquake, assessment of structural damage, analysis of earthquake characteristics, geotechnical issues that may affect the damage and high ground shaking along with an assessment of geophysical and geological characteristics of region are discussed.

\section{Geological and geotechnical properties of Bornova Plain}

Manavkuyu neighborhood in Bornova Plain is severely affected from ground shaking, and the local soil effects caused amplification of the earthquake ground shaking. Moreover, the report published by Ministry of Environment and Urbanisation [21] reveal that, majority of the damage is concentrated in Bayrakli and Bornova Districts (32\% of totally collapsed buildings, $85.7 \%$ of buildings which are decided to be immediately demolished, 32 and $35.7 \%$ of heavily and moderately damaged buildings). Therefore, this plain, which is known to be affected from basin effects, is selected to be the zone of interest.

\subsection{Geology of the study area}

The Bornova Melange rocks are basement rocks in the Izmir city (Fig. 2) [22]. Bornova melange rocks are made up of sandstone-shale, limestone lenses, limestone, serpentinite and mafic volcanic blocks [23]. Upper Cretaceous-Paleocene age Bornova Melange developed in flysch facies (Fig. 2). The main component of the flysch matrix of the Bornova Melange is shale. Bornova Melange is highly folded and fractured by the effect of tectonic activities [24]. The rocks are intensively fractured, and two to four sets of joints have been recognized [25].

Neogene sedimentary rocks discordantly overlie the melange, and they consist of conglomerate, sandstone, mudstone, siltstone, and limestone lithologies. The contact between the Bornova melange and the sedimentary rock units is faulted in the study area [26].

The Upper Miocene and Pliocene volcanics, mainly consisted of dasitic tuff, dasitic lava and andesitic lava subunits, were identified and then mapped [25,27]. Cooling joints are perpendicular to the flow bands. Faults and shear zones are developed in the andesitic and dasitic volcanics. Shear zones, parallel to the cooling joints striking in NE-SW direction, are widespread in south of the Izmir bay [24,28]. Andesitic volcanics in the southern Izmir Bay overlie the clayey and marly levels of Neogene aged sedimentary rocks [25]. These volcanics generally have tuffs at the base and are continuous with agglomerate and andesitic lavas [25].

The fault traces of the Izmir city centre and its surroundings is shown in Fig. 2, based on systematic field works. Big regional faults and series of closely spaced smaller faults in and around the Izmir region are accompanied by thick rock crushing and intensive jointing zones [25].

Alluvial sediments are observed in the Bornova Plain and in the surrounding stream beds (Fig. 3). Alluvium discordantly overlies above mentioned geological units. Alluvium is mostly encountered in Alsancak, Gökdere, Yenişehir, Çamdibi, Altındağ, Doğanlar, Manavkuyu, Evka-3 neighborhoods in Bayraklı, Bornova and Konak Districts in the Bornova Plain. Alluvial plains exist around the Izmir Bay which was developed on the same terrestrial fills. But their geomorphological aspects are different. Alsancak in the south and Karşıyaka in the north are delta plains developed in front of the mountain rivers [29]. Bornova Plain in the east starts with the Izmir Bay's shore and it is not a typical 



Gravelstone (Neogene)
Gravelstone (Cretaceous)
Volcanic rocks (Cretaceous)
Sandstone-Mudstone Intercalations
Fault breccia
Calcareous shale (Cretaceous)
Limestone (Cretaceous)

Fig. 2. Local geology of the Bornova Plain and surroundings including the area of investigation, which is further detailed in Figs. 4 and 5 (Reproduced from [22]).

delta plain. First of all, Bornova Plain is a sedimentary basin between mountains. Different soils in the basin formed due to hydro-geomorphological properties of streams, which cause accumulation of alluvial geomaterials into Bornova Plain. There are three mountain streams flowing through Bornova ending in Izmir Bay. These are Kocaçay in the north; Gökdere (Arap stream) which comes from west of the Kurudağ Hill and forms Işıkkent accumulation cone, and Kavaklidere (Manda River) in the east [22,29].

\subsection{Evaluation of soil types in the alluvium}

Kıncal [22] compiled a total of 167 soil investigation reports, which are the results of investigations performed in Bornova Plain. UTM (Universal coordinates of each borehole were determined and digitized using a Mapinfo GIS software. Figs. 4 and 5 include thematic maps of average Standard Penetration blow counts from upper $3 \mathrm{~m}$ and topmost layer soil types underlying the investigation area. Fig. 4 also includes information about distribution of the damaged buildings within the investigation area. It should be noted that, topsoils in the area are mostly composed of soils dominantly having a SPT-blow counts ranging between 0 and 20. Topsoils in the area are mostly classified as mixtures of silt, sand and clay and fill (Fig. 5). Needless to say, the engineering properties of the topsoils are very poor, and these values are also approved by the geophysical measurements in the area: low values of average shear wave velocity and a deep bedrock. According to many studies in literature concerning the characteristics of soils of Bornova Plain, including Manavkuyu neighborhood and its surroundings [17,22, $30-32]$, it was observed that the engineering bedrock $\left(V_{s}>760 \mathrm{~m} / \mathrm{s}\right)$ for Bornova Plain reached depths of $400-450 \mathrm{~m}$ and had a concave structure leading to a basin effect (Fig. 6). Coupled with the basin effects, these 


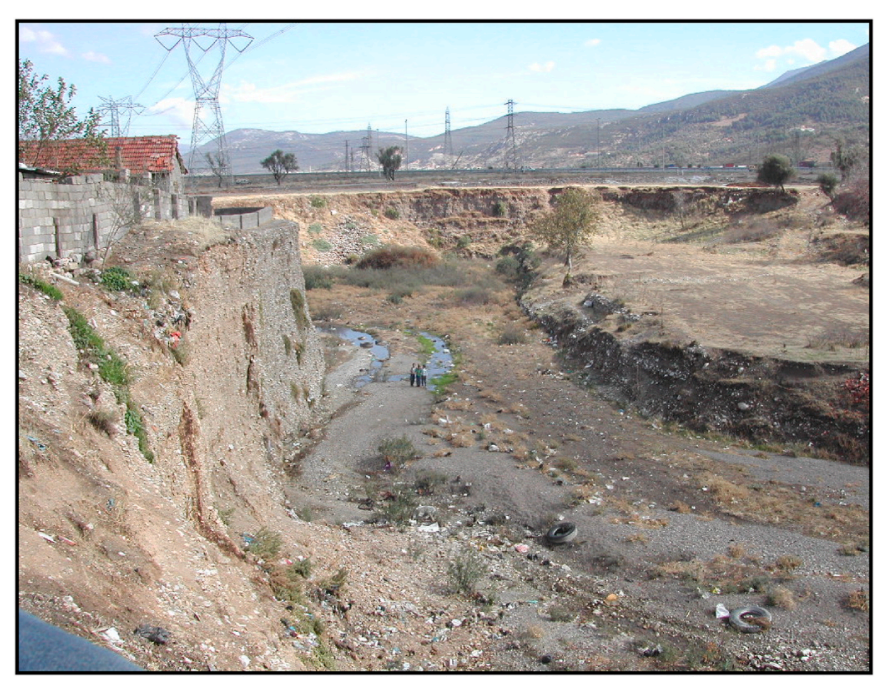

Fig. 3. Alluvium exposed in the eastern part of the Bornova Plain [22].

soils are prone to amplify the ground shaking and have a considerable liquefaction potential.

\subsection{Spectral characteristics of the earthquake records}

During the past decade, a wide-range earthquake monitoring system has been installed by the Disaster and Emergency Management Presidency (AFAD) in Turkey, to acquire strong ground motion records within national borders. In this context, totally 22 accelerometers have been installed to different locations of the Izmir province (Fig. 7 and Table 1). In Fig. 8, five ground acceleration time-histories, which were recorded at Buca, Bayraklı, Güzelbahçe, Konak and Karşıyaka stations of main shock are presented, respectively [33]. Among these, although the Güzelbahçe station is the closest one to the epicentre of the earthquake, the largest amplitudes for the recorded accelerations are observed in Konak, Bayraklı and Karşıyaka stations, which are rather far away from the earthquake source.

Fig. 9 presents the Power Spectral Density (PSD) spectra for the recorded accelerations. At first sight, one can observe that the acceleration time histories recorded in Konak, Bayraklı and Karşıyaka stations show larger amplitudes at the lower frequencies. In other words, a significant amplification can be expected in these regions especially for the structures of which fundamental periods vary between 0.5 and $2.0 \mathrm{~s}$. This situation can be better illustrated through the response spectra obtained from the records. In this context, the pseudo acceleration as well as the velocity and displacement response spectra evaluated for the considered records are presented in Fig. 10. Here, the given spectra are evaluated considering a $5 \%$ modal damping ratio which is frequently assumed for reinforced concrete buildings in Turkey. Similarly, one can deduce that the records from the Konak, Bayraklı and Karşıyaka stations produce larger responses for the periods between 0.5 and $2.0 \mathrm{~s}$. However, according to the field investigations, it is observed that the vast majority of the heavily damaged and/or collapsed buildings are concentrated in the Bayraklı region. This observation is also compatible with the results reported by AFAD [21]. A similar trend can be observed in the presented velocity and displacement response spectra. Particularly, the displacement response spectra for Bayraklı district reveal that the largest elastic displacement demand is observed in the lateral directions. This observation may also be considered as one of the major reasons why Bayraklı district experienced the most severe damage, and all the collapsed buildings are located in this region. Field observations also reveal that a considerable amount of the heavily damaged and/or collapsed buildings have number of stories varying between 6 and 12, damage likely to occur can also be observed from spectra. The spectra plotted for stronger zones (e.g. Buca) provide peak values between the periods of 0.1 and $0.3 \mathrm{~s}$, and observed damage are considerably lower. In Bayraklı region, the observed damage can be associated with resonance phenomenon partially triggered by double resonance effect and low structural quality of the collapsed and heavily damaged buildings constructed in the twenty years period after 1980. A more comprehensive discussion of structural aspects will be undertaken in Section 3.

Comparisons between the elastic response and design spectra of Karşıyaka and Bayraklı station records according to 1975, 2007 and 2018 Earthquake Codes are presented in Figs. 11-13, respectively. Here, the latest two versions of Turkish Earthquake Code (TEC) is considered $[34,35]$, in addition to an older version $[36,10]$ : is not included in this comparison since its design spectrums are completely same with [34]. In TEC 1975 [36]; a rough design spectrum represented by an equivalent inelastic response was presented [37]. Therefore, the available design spectrum which comprises four different soil conditions is transformed to the elastic response, considering the response modification factors (R)

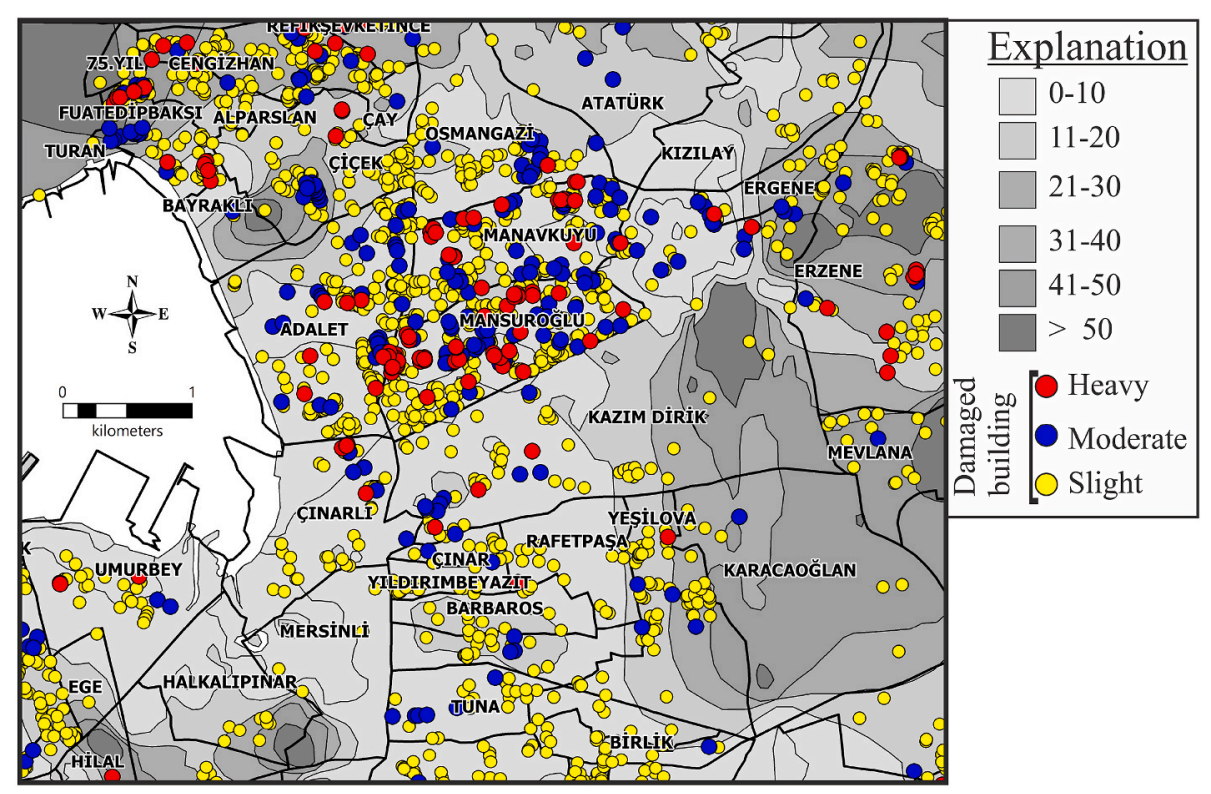

Fig. 4. SPT zoning map for $3 \mathrm{~m}$ depth from the ground surface including locations of damaged buildings. 


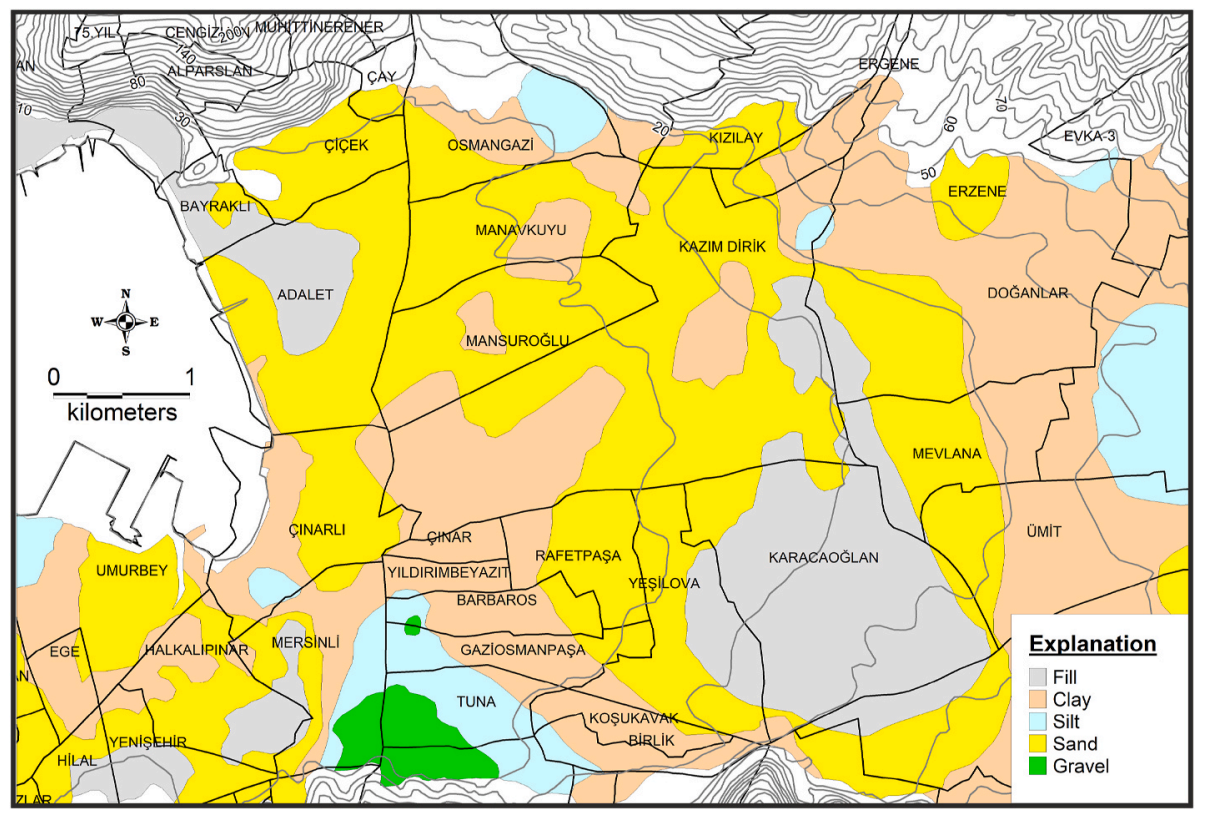

Fig. 5. Map of soil types down to $3 \mathrm{~m}$ depth from the surface (Reproduced from Ref. [22]).

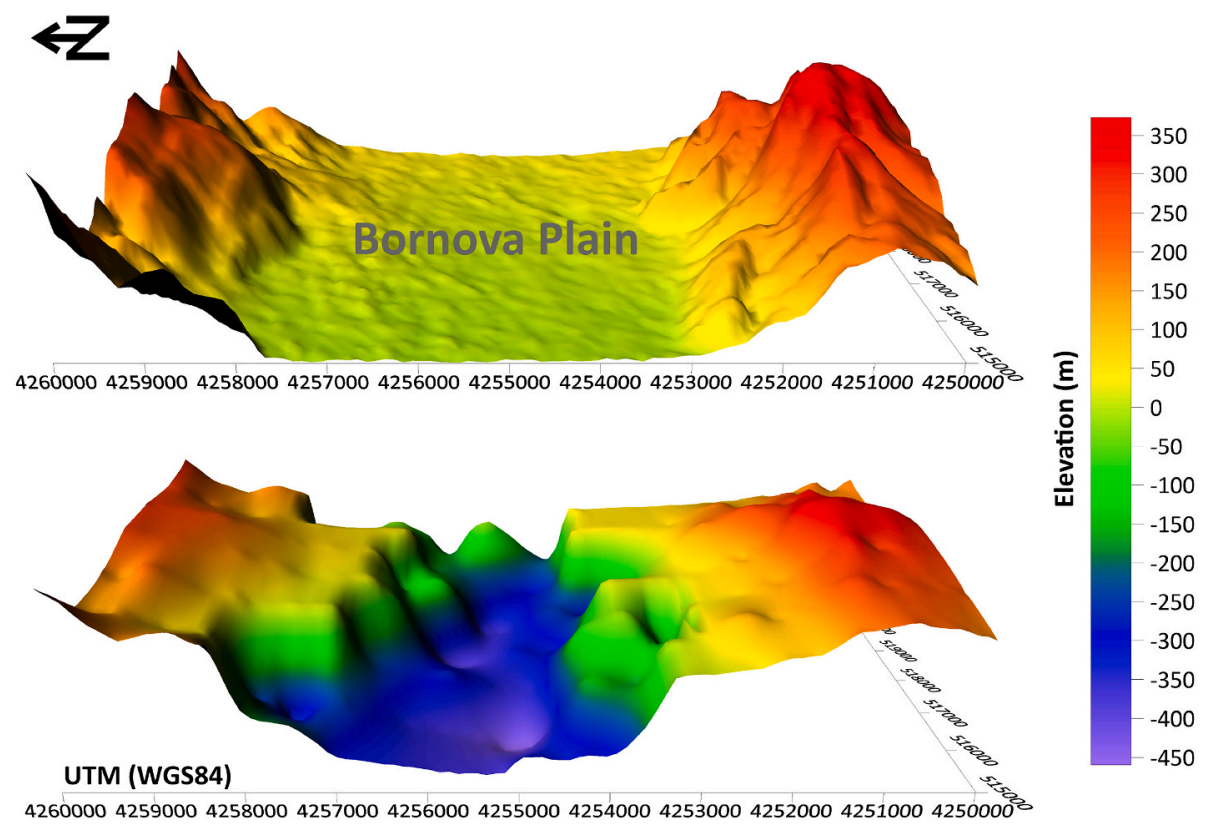

Fig. 6. Topography (Upper) and Engineering Bedrock depth (Lower) map of the Bornova Plain (Reproduced from Pamuk et al. [32]).

as 6 and 8 , respectively. Here, $\mathrm{R}=8$ indicates the modification factor defined for moment frames, and $\mathrm{R}=6$ represents the structural systems composed by shear walls. Similarly, in TEC 2007 [34]; the spectrum curves are plotted with respect to four soil types, namely, Z1, Z2, Z3 and $\mathrm{Z} 4$, which represents the soil conditions from stronger to weaker (Tables 2 and 3). In TEC 2019 [35]; predefined spectrum values are presented in Turkey Earthquake Hazard Map (for 475 years return period with $10 \%$ probability of exceedence-Earthquake Level DD2), considering five soil types named as ZA, ZB, ZC, ZD and ZE. Apart from these five, soft soils, organic soils, liqufiable soils, etc. are evaluated as ZF type, which needs site specific ground response analysis. The presented spectra reveal that the acceleration responses for the periods between 0.5 and $1.5 \mathrm{~s}$ exceed the design values for strong soils. However, considering the weak soil types, observed spectrum values remain lower than the design values. This situation can be observed for the design spectra proposed by Refs. [34-36].

\subsection{Preliminary assessment of local site effects}

\subsubsection{Site amplification and resonance phenomenon}

Underlying geological formations and local soil conditions in a specific zone greatly affect the characteristics of surface ground motion during seismic excitation. During 2020 Samos Earthquake, it is evident that Bayrakli District suffered from poor performance of underlying deep, soft alluvial sediments combined with evident basin effect, which may have led to prolonged site amplification and resonance phenomenon. This phenomenon is related with geotechnical properties of the region as well as structural properties. During the earthquake, a limited number of buildings were slightly damaged in Seferihisar District, which is relatively close to the epicentre of the earthquake $(\sim 30 \mathrm{~km})$ and 


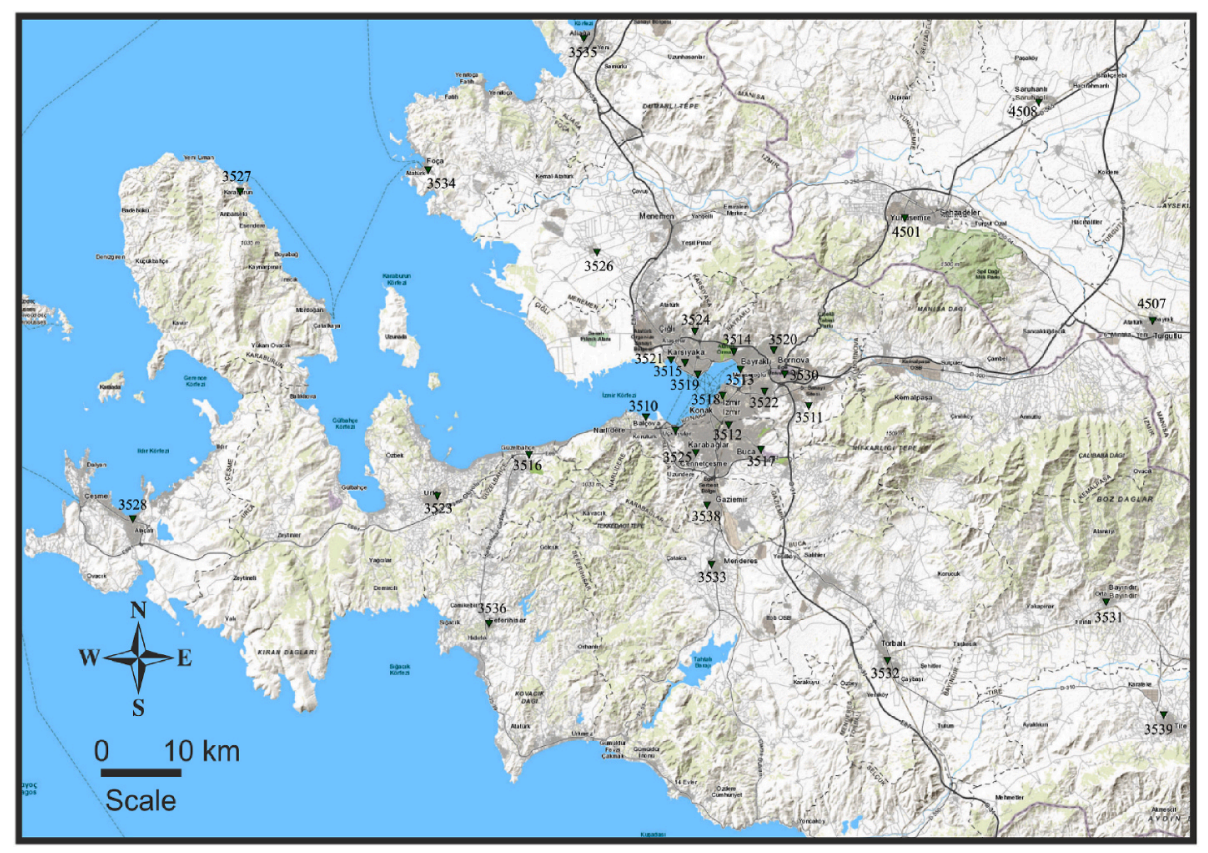

Fig. 7. Strong ground motion stations in the vicinity of Izmir city center.

where the buildings are dominantly low-rise. On the other hand, 20 buildings collapsed, and many were heavily damaged during the earthquake in Manavkuyu neighborhood which is approximately $75 \mathrm{~km}$ far away from the epicentre (Fig. 1). Collapsed and heavily damaged structures were mostly composed of 6 to 12-storeys, while minor damage was reported for buildings with number of storeys outside of this range [37-39]. The effects and consequences are quite similar to those of 1985 Michoacan $\left(M_{s}\right.$, surface wave magnitude of 8.1) earthquake in Mexico City [40]. A vast damage occurred during shaking in Mexico City, $350 \mathrm{~km}$ far away from the epicentre. The soil profile underlying the Lake Zone (the most influenced region) consists of soft soils down to a depth of 38-50 m. Heavily damaged superstructures are observed to be constituted of 5-20 storeys, whereas the level of damage is lower in low-rise and in extremely high-rise buildings.

The concentration of damage and collapse of buildings with only a certain number of storeys can be explained with the resonance phenomenon, which can be pronounced when natural vibration period of the superstructure matches that of the soil. Stanko et al. [41]; by using predominant periods of soil and structure, presented a relationship indicating potential of soil-structure resonance. In this way, resonance potential is calculated by dividing the absolute value of the difference between predominant period of soil and natural vibration period of structure by predominant period of soil. Rewriting in terms of percentages, when this parameter ranges among $0-15 \%$, then, a high potential of soil-structure resonance is likely. On the other hand, values between 15 and $25 \%$ and greater than $25 \%$ are defined as medium and low, respectively.

In order to obtain both predominant period of soil and soil amplification, Standard Spectral Ratio (SSR) and Horizontal to Vertical Spectral Ratio (HVSR) parameters were used. SSR [42] is used to evaluate local site effects using data from shallow soft layers and underlying bedrock. It is also applicable at the ground surface if rock outcrops exist. Maximum value of the spectral ratio gives information about the period where soil amplification occurs, which is defined as soil predominant period. In HVSR method [43], amplification and predominant period of soil are obtained from spectral ratios, as well. The difference is the use of horizontal and vertical measurements in the HVSR method. Spectral ratios can be obtained from Fourier Amplitude Spectra (FAS) or Pseudo Acceleration Spectra (PAS). Zhu et al. [44] underlines that frequency content and scenario dependency is influential in selection of spectra.

In the context of this study, spectral accelerations obtained from several recordings of stations 3513 and 3514, are used in SSR and HVSR methods in order to evaluate the predominant period of soil and amplification. Selected recordings for different spectral ratio methods include mainshock and aftershock data. Totally, 25 recordings were selected from station 3513, in which only 15 of them were available in both stations. Station 3513, which is located on soft soil, is the one closest to the study area (Figs. 2 and 7). The altitude is $+2 \mathrm{~m}$ at this location and the value of $V_{S, 30}$ beneath the station is $196 \mathrm{~m} / \mathrm{s}$. On the other hand, station 3514 is located in Cengizhan Neighborhood of which the altitude is $+197 \mathrm{~m}$ (Figs. 2 and 7). The $\mathrm{V}_{\mathrm{S}, 30}$ value of the soil profile is $836 \mathrm{~m} / \mathrm{s}$. It is the nearest rock outcrop station to the study area and recordings were only used in SSR method.

Recordings of earthquakes with the magnitude larger than $4.0\left(\mathrm{M}_{\mathrm{L}}\right.$ and $\mathrm{M}_{\mathrm{W}}$ ) were taken into consideration. Various parameters belonging to the selected recordings are given in Tables 4 and 5 for stations 3513 and station 3514, respectively. The values of peak spectral acceleration (PGA), peak ground velocity (PGV), peak ground displacement (PGD) and pseudo-spectral acceleration at specific periods (PSA) are tabulated.

The predominant period of soil and amplification, which were evaluated using SSR and HVSR methods (Fig. 14), are given in Table 6. Values based on main shock from SSR shows a good match between E-W and N-S directions while those from HVSR do not. Predominant period of soil was evaluated as $1.44 \mathrm{~s}$ from SSR and as $1.63 \mathrm{~s}$ from HVSR. Accordingly, soil amplifications were evaluated as 4.70 and 4.25 from SSR and HVSR, respectively. Each of these values were calculated as the arithmetic mean of spectral ratios in E-W and N-S directions.

The soil-structure resonance potential [41] can be described in terms of vibration period. The predominant period of soil was found as $1.44 \mathrm{~s}$ and $1.63 \mathrm{~s}$. According to Stanko et al. [41]; depending upon varying structural vibration periods, ranges of period could be defined for low, medium and high levels of resonance potential. For periods $\leq 1.44 \mathrm{~s}$, the range of high, medium and low potential levels are $1.20 \mathrm{~s}-1.44 \mathrm{~s}, 1.08$ $\mathrm{s}-1.20 \mathrm{~s}$ and $<1.08 \mathrm{~s}$, respectively. Accordingly, for periods $\geq 1.63 \mathrm{~s}$, the range of high, medium and low potential levels are $1.63 \mathrm{~s}-1.88 \mathrm{~s}, 1.88$ $\mathrm{s}-2.04 \mathrm{~s}$ and $>2.04 \mathrm{~s}$, respectively. The resonance potentials which are likely for buildings in Manavkuyu Neighborhood are listed in Table 7 depending upon natural vibration period, which is in turn related with 
Table 1

Properties of strong ground motion stations and underlying soil profile given in Fig. 7.

\begin{tabular}{|c|c|c|c|c|c|c|c|c|c|c|}
\hline $\begin{array}{l}\text { Station } \\
\text { code }\end{array}$ & District & $\begin{array}{l}\text { Northing } \\
\left({ }^{\circ}\right)\end{array}$ & $\begin{array}{l}\text { Easting } \\
\left({ }^{\circ}\right)\end{array}$ & $\begin{array}{l}\text { Elevation } \\
(\mathrm{m})\end{array}$ & $\begin{array}{l}\text { Epicentral } \\
\text { distance }(\mathrm{m})\end{array}$ & Lithology & $\begin{array}{l}\text { Predominant } \\
\text { Frequency }(\mathrm{Hz})\end{array}$ & $\begin{array}{l}\mathrm{V}_{\mathrm{s}, 30} \\
(\mathrm{~m} / \mathrm{s})\end{array}$ & $\begin{array}{l}\text { EC soil } \\
\text { class }\end{array}$ & $\begin{array}{l}\text { TEC soil } \\
\text { class }\end{array}$ \\
\hline 3535 & Aliağa & 38.79629 & 26.96323 & 17 & 104.61 & $\begin{array}{l}\text { Unclassified } \\
\text { Quaternary deposits }\end{array}$ & 3.50 & 361 & B & $\mathrm{ZC}$ \\
\hline 3510 & Balçova & 38.40900 & 27.04300 & 3 & 66.08 & $\begin{array}{l}\text { Unclassified } \\
\text { Quaternary deposits }\end{array}$ & 0.50 & 313 & $\mathrm{C}$ & ZD \\
\hline 3511 & Bornova & 38.42130 & 27.25630 & 76 & 77.40 & Terrestrial sediments & 5.50 & 827 & A & $\mathrm{ZB}$ \\
\hline 3512 & Buca & 38.40090 & 27.15160 & 79 & 70.13 & Lacustrine carbonates & 1.80 & 468 & B & $\mathrm{ZC}$ \\
\hline 3513 & Bayraklı & 38.45840 & 27.16710 & 2 & 76.22 & $\begin{array}{l}\text { Unclassified } \\
\text { Quaternary deposits }\end{array}$ & 0.70 & 196 & $\mathrm{C}$ & ZD \\
\hline 3514 & Bayraklı & 38.47620 & 27.15810 & 197 & 77.50 & Pyroclastic rocks & - & 836 & A & ZB \\
\hline 3515 & Karşıyaka & 38.46490 & 27.09400 & 4 & 73.65 & $\begin{array}{l}\text { Unclassified } \\
\text { Quaternary deposits }\end{array}$ & 0.40 & 171 & $\mathrm{D}$ & $\mathrm{ZE}$ \\
\hline 3516 & Güzelbahçe & 38.37060 & 26.89070 & 17 & 57.14 & $\begin{array}{l}\text { Unclassified } \\
\text { Quaternary deposits }\end{array}$ & 0.70 & 460 & B & $\mathrm{ZC}$ \\
\hline 3517 & Buca & 38.37560 & 27.19360 & 136 & 70.01 & Lacustrine carbonates & 4.70 & 695 & B & $\mathrm{ZC}$ \\
\hline 3518 & Konak & 38.43120 & 27.14350 & 7 & 72.56 & $\begin{array}{l}\text { Unclassified } \\
\text { Quaternary deposits }\end{array}$ & 0.70 & 298 & $\mathrm{C}$ & ZD \\
\hline 3519 & Karşıyaka & 38.45250 & 27.11120 & 10 & 73.16 & $\begin{array}{l}\text { Unclassified } \\
\text { Quaternary deposits }\end{array}$ & 0.40 & 131 & $\mathrm{D}$ & $\mathrm{ZE}$ \\
\hline 3520 & Bornova & 38.47800 & 27.21110 & 184 & 80.14 & Pyroclastic rocks & - & 875 & A & $\mathrm{ZB}$ \\
\hline 3521 & Karşıyaka & 38.46792 & 27.07636 & 1 & 73.25 & $\begin{array}{l}\text { Unclassified } \\
\text { Quaternary deposits }\end{array}$ & 0.30 & 145 & $\mathrm{D}$ & $\mathrm{ZE}$ \\
\hline 3522 & Bornova & 38.43570 & 27.19870 & 68 & 75.65 & $\begin{array}{l}\text { Unclassified } \\
\text { Quaternary deposits }\end{array}$ & 0.90 & 249 & $\mathrm{C}$ & ZD \\
\hline 3523 & Urla & 38.32820 & 26.77060 & 76 & 50.35 & Marl & 1.40 & 414 & B & $\mathrm{ZC}$ \\
\hline 3524 & Karşıyaka & 38.49690 & 27.10730 & 64 & 77.35 & Tuff & 7.00 & 459 & B & $\mathrm{ZC}$ \\
\hline 3525 & Karabağlar & 38.37230 & 27.10840 & 106 & 65.39 & $\begin{array}{l}\text { Terrestrial sediments } \\
\text { and carbonates }\end{array}$ & 14.00 & 745 & B & $\mathrm{ZC}$ \\
\hline 3526 & Menemen & 38.57823 & 26.97953 & 6 & 81.51 & $\begin{array}{l}\text { Unclassified } \\
\text { Quaternary deposits }\end{array}$ & - & 205 & $\mathrm{C}$ & ZD \\
\hline 3527 & Karaburun & 38.63903 & 26.51277 & 60 & 86.23 & Terrestrial sediments & - & 207 & $\mathrm{C}$ & $\mathrm{ZD}$ \\
\hline 3528 & Çeşme & 38.30393 & 26.37256 & 17 & 55.46 & Tuff & - & 532 & B & $\mathrm{ZC}$ \\
\hline 3530 & Bornova & 38.45302 & 27.22444 & 35 & 78.52 & $\begin{array}{l}\text { Unclassified } \\
\text { Quaternary deposits }\end{array}$ & - & 270 & $\mathrm{C}$ & ZD \\
\hline 3531 & Bayındır & 38.22026 & 27.64853 & 104 & 91.18 & Alluvial fan deposits & 2.30 & 271 & $\mathrm{C}$ & ZD \\
\hline 3532 & Torbalı & 38.15911 & 27.35956 & 39 & 65.48 & $\begin{array}{l}\text { Unclassified } \\
\text { Quaternary deposits }\end{array}$ & 1.70 & 328 & $\mathrm{C}$ & ZD \\
\hline 3533 & Menderes & 38.25717 & 27.13017 & 127 & 56.34 & $\begin{array}{l}\text { Unclassified } \\
\text { Quaternary deposits }\end{array}$ & 4.07 & 415 & B & $\mathrm{ZC}$ \\
\hline 3534 & Foça & 38.66241 & 26.75856 & 13 & 87.34 & $\begin{array}{l}\text { Unclassified } \\
\text { Quaternary deposits }\end{array}$ & - & 328 & $\mathrm{C}$ & ZD \\
\hline 3536 & Seferihisar & 38.19681 & 26.83839 & 34 & 37.32 & $\begin{array}{l}\text { Unclassified } \\
\text { Quaternary deposits }\end{array}$ & 6.90 & 1141 & A & ZB \\
\hline 3538 & Gaziemir & 38.31870 & 27.12335 & 168 & 61.25 & - & - & - & - & - \\
\hline 3539 & Tire & 38.10229 & 27.72105 & 90 & 92.71 & - & - & - & - & - \\
\hline 4501 & Yunusemre & 38.61259 & 27.38138 & 106 & 100.93 & - & - & 340 & - & ZD \\
\hline 4507 & Turgutlu & 38.50748 & 27.70610 & 88 & 112.23 & Alluvial fan deposits & 0.74 & 341 & $\mathrm{C}$ & $\mathrm{ZD}$ \\
\hline 4508 & Saruhanlı & 38.73237 & 27.55679 & 38 & 120.78 & $\begin{array}{l}\text { Unclassified } \\
\text { Quaternary deposits }\end{array}$ & 0.95 & 229 & $\mathrm{C}$ & ZD \\
\hline
\end{tabular}

number of storeys. As a rule of thumb, the structural vibration period of an $\mathrm{N}$-storey building in static conditions is approximately calculated by $0.10 \times \mathrm{N}$.

Results show that 13 to 18 -storey buildings have high potential of resonance. On the other hand, 11 to 12 and 19 to 20-storey buildings exhibit medium resonance potential. In Manavkuyu neighborhood, buildings with 6-12 storeys showed poor performance although they were expected to have low potential of resonance. The underlying reason may well be the increase in resonance potential due to elongation of fundamental vibration period during the excitation. However, contribution of soil nonlinearity and basin effects should be taken into consideration for more detailed evaluation.

\subsubsection{Considerations on soil nonlinearity}

Nonlinear behaviour of soils during seismic excitation is an essential phenomenon to be considered for an adequate interpretation of local site effects and soil-structure interaction effects which may cause varying levels of damage to buildings. Degradation of shear modulus and increase in damping with an increase in shear strain are the main indicators of soil nonlinearity. This may lead to reduction in soil amplification and shift of predominant period of the soil towards longer periods due to reduction in shear modulus. Cyclic degradation effects can enhance this behaviour especially starting from shear strain $(\gamma)$ levels of $10^{-4}$. Fig. 15 which is originally prented by Ishihara [45] exhibits the strain dependency of nonlinear phenomena in soils during seismic excitation.

Nonlinearity and resulting elastoplastic/plastic deformations can be observed in areas with such thick and low strength soil layers and in non-consolidated alluvial soil deposits. Level of nonlinearity in soil layers can be traced by shear strain level. In order to have a preliminary idea about the shear strain level which may have been produced in Bornova Plain during the main shock, relationship by Ref. [46] has been applied to the data from station 3513.

$\gamma_{\text {eff }}=0.4 V_{\max } / V_{S l}$

where $V_{\max }, V_{S l}$ and $\gamma_{\text {eff }}$ are peak velocity, shear wave velocity and effective shear strain, respectively.

To investigate this phenomenon, a ground model was created by using the 3513 station ground boring $\log$, by use of SPT- $\mathrm{N}_{30}$ values (number of blows required for $30 \mathrm{~cm}$ penetration of sampler), and 1D SWave Velocity values obtained from the MASW (multi-channel analysis 

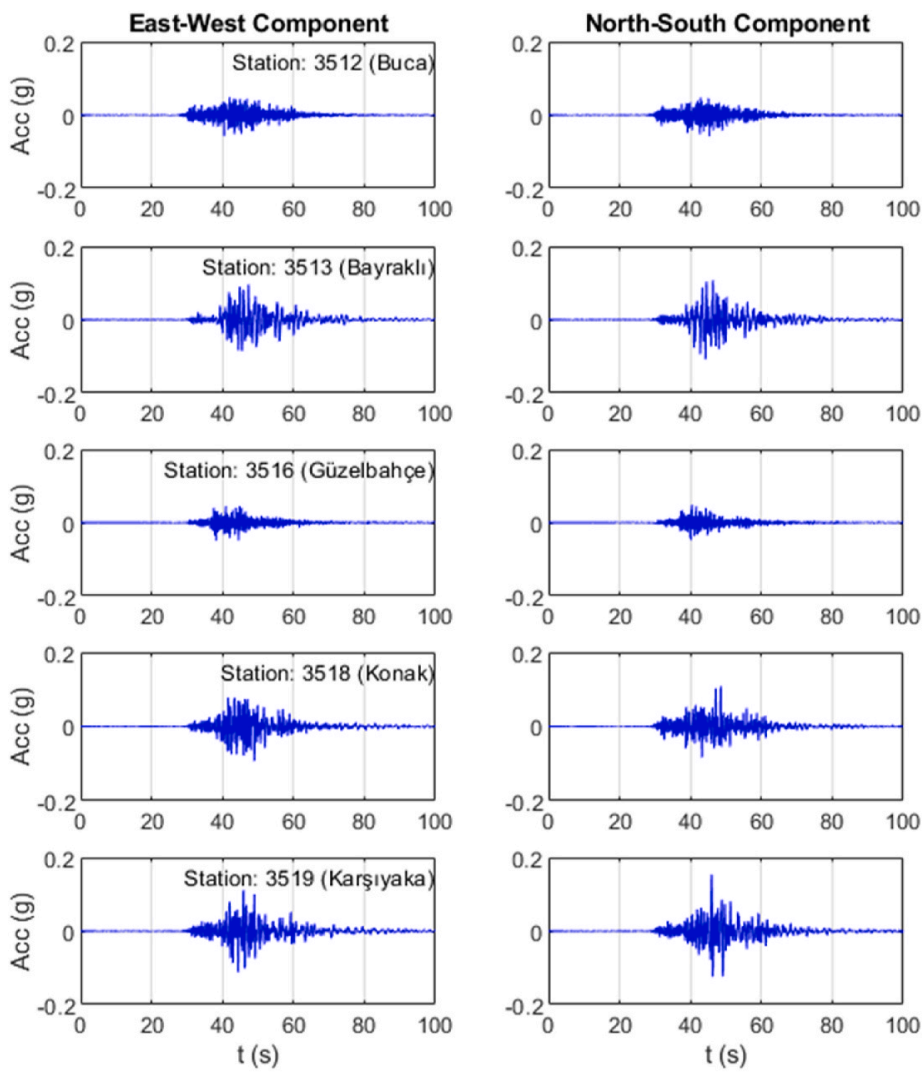
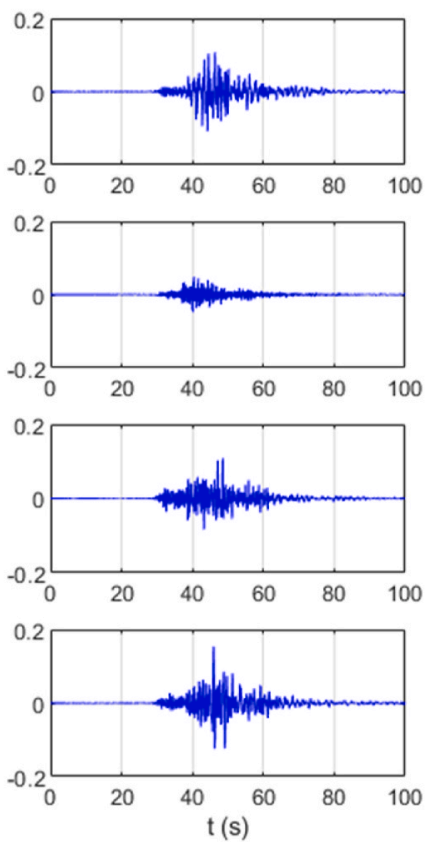
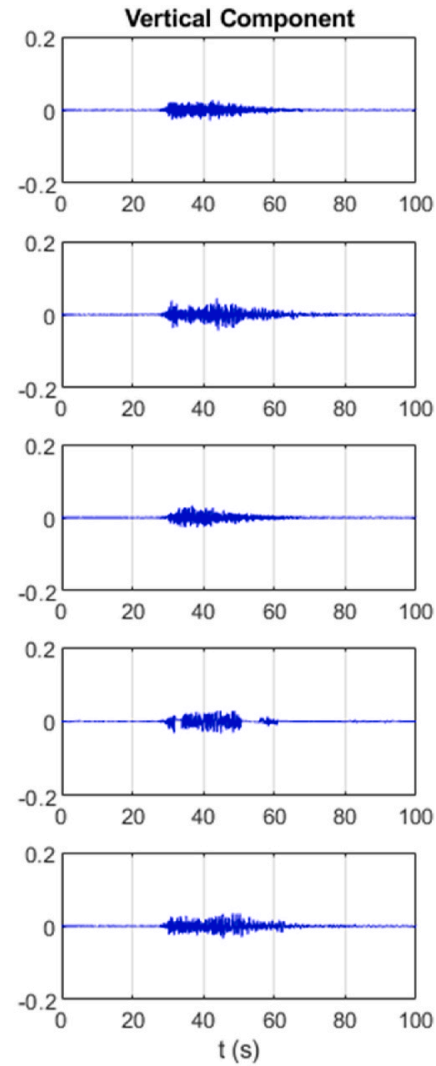

Fig. 8. Recorded acceleration time histories in East-West, North-South and Vertical directions.
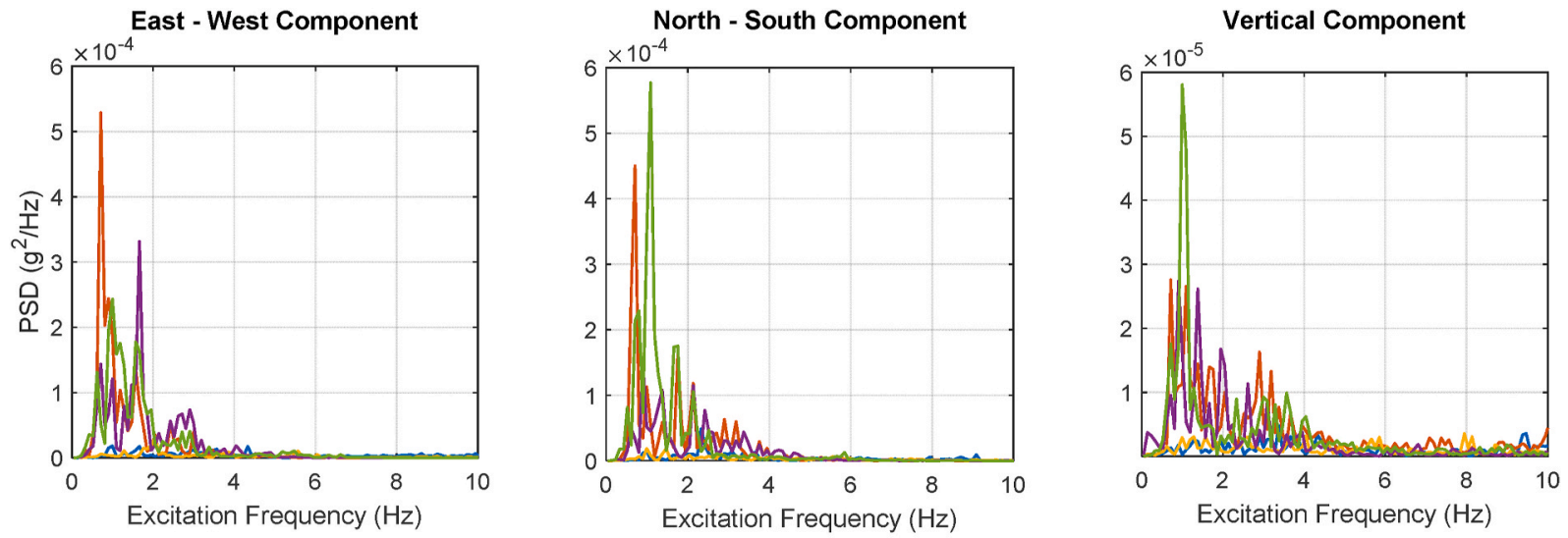

- Buca (3512)

Bayraklı (3513)

- Güzelbahçe(3516)

Konak (3518)

Karşıyaka (3519)

Fig. 9. Power Spectral Density (PSD) spectra for the recorded accelerations.

of surface waves) method for $30 \mathrm{~m}$ depth [12] (Fig. 16). The boring log shows that the ground is composed of clayey silty sandy units for the first $30 \mathrm{~m}$ depth. SPT-N 30 values vary between 7 and 23 whereas S-Wave velocity values range among 127 and $254 \mathrm{~m} / \mathrm{s}$.

When these parameters are analysed together, it is evident that the ground consists of units with low strength for the first $30 \mathrm{~m}$ depth, which may exhibit nonlinear behaviour under seismic action. Using these parameters, an idealized 5-layer soil model is created (Fig. 16, Table 8). By using this 1D ground model, 1D Equivalent Linear Seismic Site Response analyses were performed by use of NS and EW component of acceleration records for Samos Earthquake obtained from station 3513. The acceleration data recorded at the station 3513 on the ground surface were transferred to the interface of these 5 soil layers by deconvolution process. Afterwards, the acceleration records obtained for each layer interface were converted into velocity records and later, peak velocity $\left(V_{\max }\right)$ values were obtained. By using these peak velocity values and $\mathrm{S}$ wave velocities of the soil layers $\left(V_{S l}\right)$, effective shear strain $\left(\gamma_{e f f}\right)$ values were obtained by making use of Equation (1) [47] (Table 8). Midorikawa [48] emphasized that the effect of the nonlinearity becomes significant when the strain in topmost soil layer is larger than approximately $3 \times 10^{-4}$.

Nakamura [49] made suggestions for the prediction of damage that may occur during earthquakes with the concept of $K_{g}$, the damage coefficient (Equation (2)). In Equation (2), $A$ represents maximum amplitude of spectra and $f_{o}$ is the predominant vibration frequency. After the 1989 Loma-Prieta earthquake, the $K_{g}$ values calculated from 

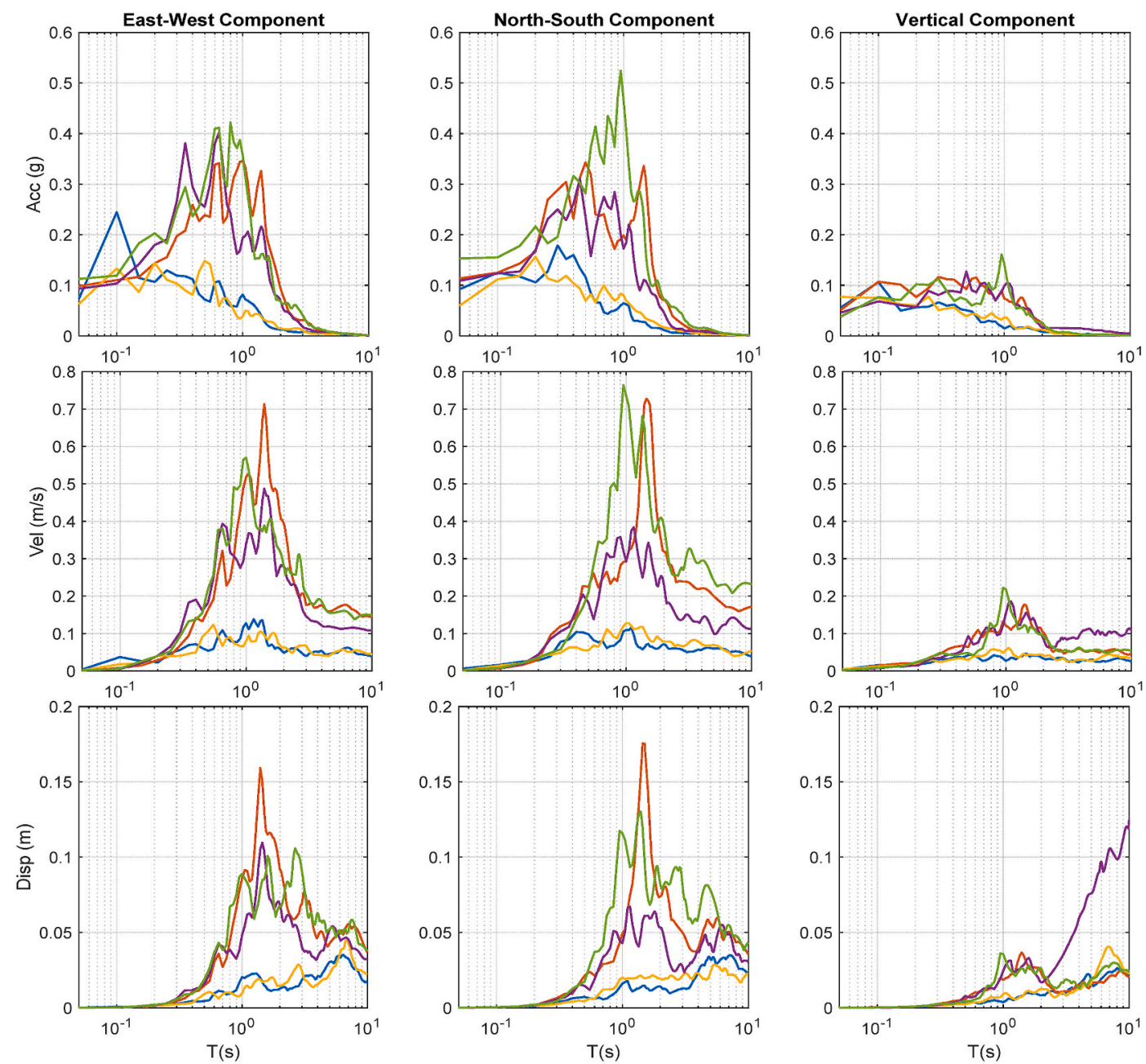

Buca (3512) — Bayraklı (3513) — Güzelbahçe(3516)

Konak (3518) $=$ Karşıyaka (3519)

Fig. 10. Acceleration, velocity and displacement response spectra obtained for available records.

a-) Bayraklı Station

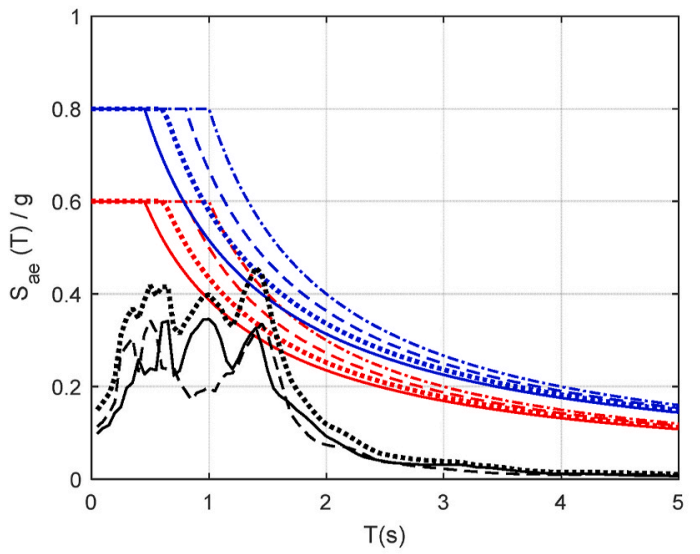

b-) Karşıyaka Station

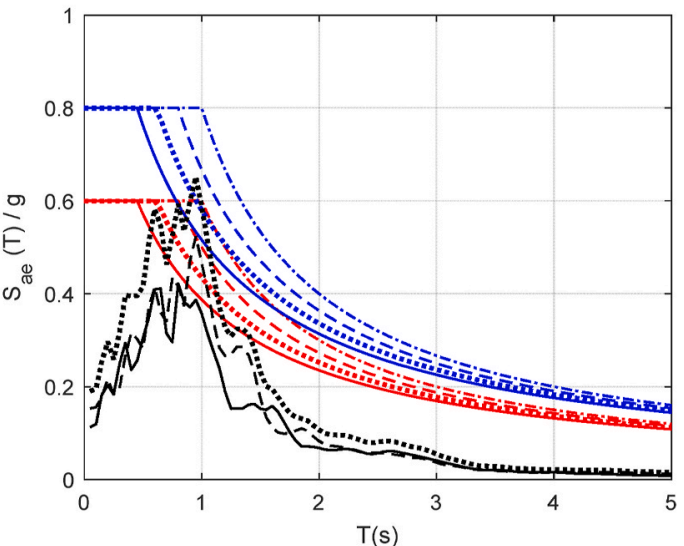

$\mathrm{T}(\mathrm{s})$

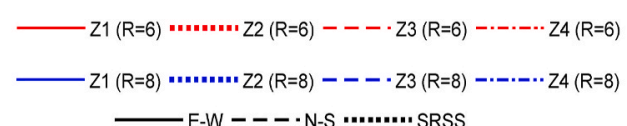

Fig. 11. Acceleration response spectra for Bayrakli and Karsiyaka records as well as the design spectra according to TEC 1975 [36] (For Earthquake Level 1). 
a-) Bayraklı Station

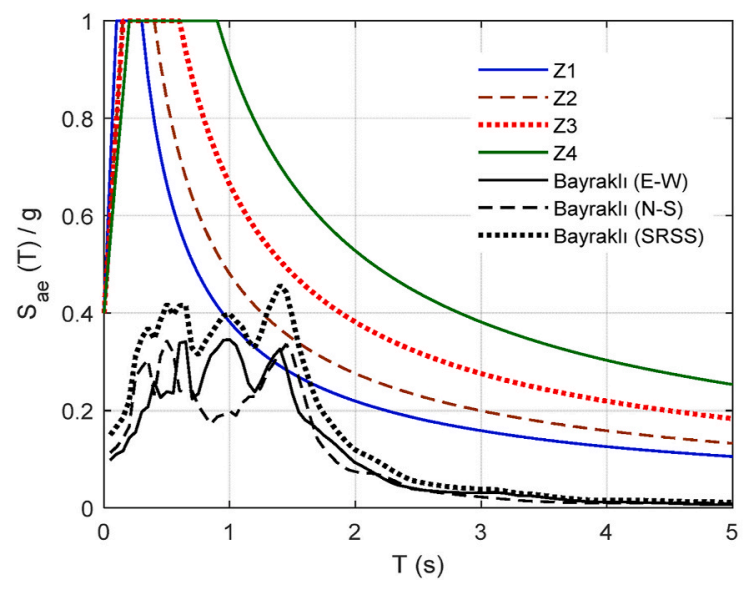

b-) Karşıyaka Station

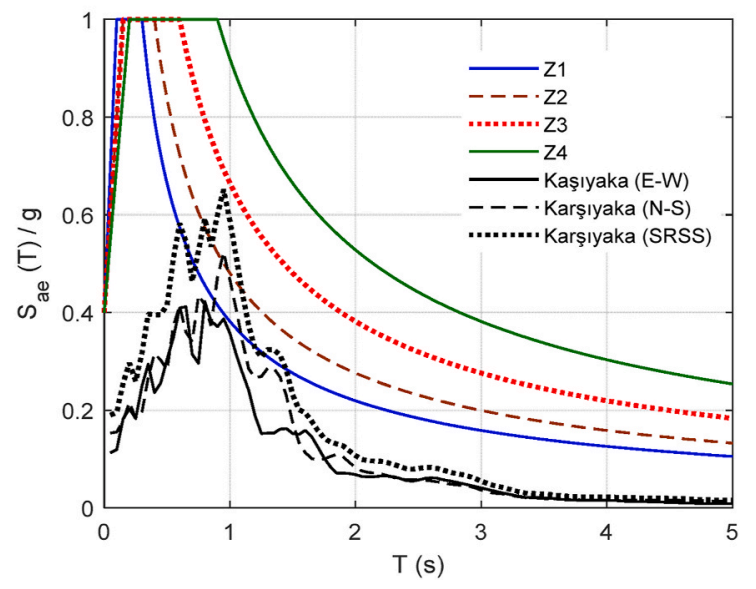

Fig. 12. Acceleration response spectra for Bayrakli and Karsiyaka records as well as the design spectra according to TEC 2007 [34] (For Earthquake Level 1).

a-) Bayraklı Station

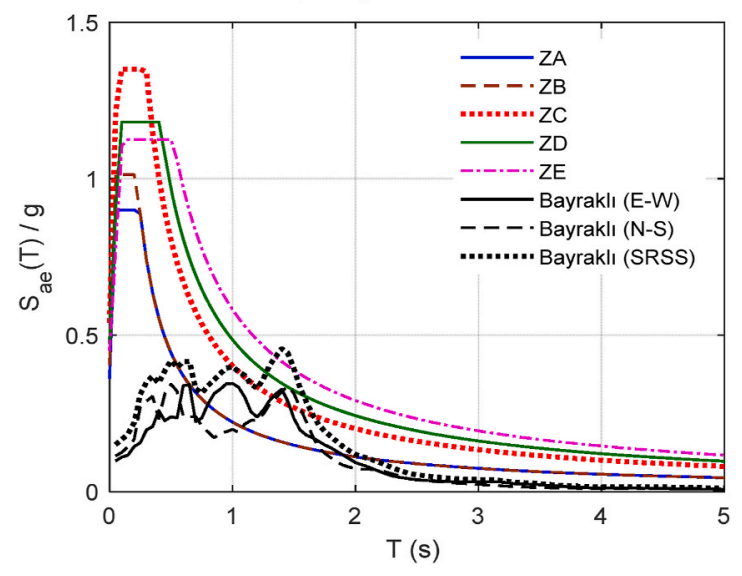

b-) Karşıyaka Station

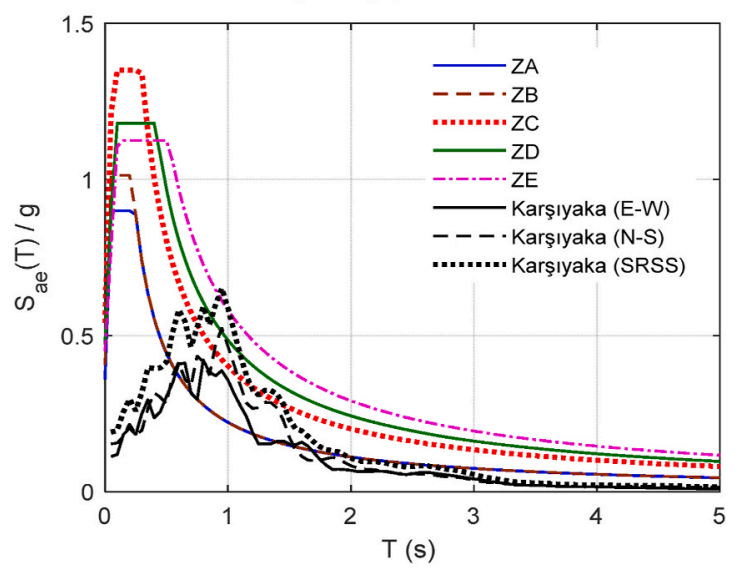

Fig. 13. Acceleration response spectra for Bayrakli and Karsiyaka records as well as the design spectra according to TEC 2019 [35] (DD2).

Table 2

Spectrum characteristic periods according to the soil classes in TEC 1998 and $2007[10,34]$.

\begin{tabular}{llll}
\hline $\begin{array}{l}\text { Local site } \\
\text { classes }\end{array}$ & $\begin{array}{l}\mathrm{T}_{\mathrm{A}} \\
{[\mathrm{s}]}\end{array}$ & $\begin{array}{l}\mathrm{T}_{\mathrm{B}} \\
{[\mathrm{s}]}\end{array}$ & Soil groups and topmost soil layer thickness \\
\hline $\mathrm{Z1}$ & 0.10 & 0.30 & $\begin{array}{l}\text { Group (A) soils; Group (B) soils with } \mathrm{h}_{1} \leq 15 \mathrm{~m} \\
\mathrm{Z} 2\end{array}$ \\
0.15 & 0.40 & $\begin{array}{l}\text { Group (B) soils with } \mathrm{h}_{1}>15 \mathrm{~m} \text {; Group (C) soils } \\
\text { with } \mathrm{h}_{1} \leq 15 \mathrm{~m}\end{array}$ \\
$\mathrm{Z3}$ & 0.15 & 0.60 & $\begin{array}{l}\text { Group (C) soils with } 15 \mathrm{~m}<\mathrm{h}_{1} \leq 50 \mathrm{~m} \text {; Group (D) } \\
\text { soils with } \mathrm{h}_{1} \leq 10 \mathrm{~m} \\
\text { Group (C) soils with } \mathrm{h}_{1}>50 \mathrm{~m} \text {; Group (D) soils } \\
\text { with } \mathrm{h}_{1}>10 \mathrm{~m}\end{array}$ \\
\hline
\end{tabular}

the HVSR/Quasi Transfer Spectra (QTS) obtained as a result of the HVSR studies carried out in the field showed that, where the $K_{g}$ was greater than 20, the damage were intensified, and the ground deformations turned into elastoplastic/plastic properties [49].

$K_{g}=A^{2} / f_{o}$

The QTS curve calculated using the mainshock acceleration records of the 3513 station Samos earthquake contains 2 main peaks (Fig. 17). $K_{g}$ values calculated separately for these two peaks took 215.12 for the $1^{\text {st }}$ and 124.45 for the $2^{\text {nd }}$ peak. When $K_{g}$ parameter and $\gamma_{\text {eff }}$ values calculated in Table 8 are compared, the nonlinearity of the soil and elastoplastic deformations on the soil approve the findings.
According to the recent studies in literature [39,50-53] evolution of stress-strain relation on site can be traced by a stress-strain proxy represented by PGA (stress proxy) - PGV/ $\mathrm{V}_{S}$ (strain proxy). In some of the studies strain proxy is represented by PGV/ $\mathrm{V}_{\mathrm{S}, 30}$. Fig. 18 shows the stress strain proxy at Station 3513 . Here, the triangle symbol represents the stress-strain proxy for the main shock and circles represent those for the aftershocks. One can observe that the main shock led to a strain proxy of $10^{-4}-10^{-3}$ indicating the possibility of considerable amount of shear strain which may have resulted in degradation of shear modulus.

\section{Preliminary damage assessment based on field observations}

In this section, a preliminary damage assessment is briefly presented based on the field observations by the authors in Bayrakli, Bornova and Karsiyaka districts. Although these three districts are far away from the epicentre of the earthquake, majority of heavily damaged structures are located above alluvial plains close to shorelines. Especially, Bayrakli district, in which all the collapsed buildings during the earthquake are located, has experienced the most severe damage after the first shock. Since the available masonry structures in these districts are mostly constructed at higher zones of better subsurface engineering properties, such structures were less affected by the first shock of the earthquake. According to the first observations, several masonry structures were reported to experience heavy damage in the Bayraklı district [2]. On the other hand, the available building stock in these districts are mostly 
Table 3

Soil groups defined in 2007 Turkish Earthquake Code [34].

\begin{tabular}{|c|c|c|c|c|c|}
\hline $\begin{array}{l}\text { Soil } \\
\text { groups }\end{array}$ & Description of soil group & $\begin{array}{l}\text { Standard } \\
\text { penetration }(\mathrm{N} / 30)\end{array}$ & $\begin{array}{l}\text { Relative } \\
\text { density }[\%]\end{array}$ & $\begin{array}{l}\text { Unconfined compressive } \\
\text { strength }[\mathrm{kPa}]\end{array}$ & $\begin{array}{l}\text { Shear wave } \\
\text { velocity }[\mathrm{m} / \mathrm{s}]\end{array}$ \\
\hline \multirow[t]{3}{*}{ A } & $\begin{array}{l}1 \text { Massive volcanic rocks, unweathered sound metamorphic rocks, stiff } \\
\text { cemented sedimentary rocks }\end{array}$ & - & - & $>1000$ & $>1000$ \\
\hline & 2 Very dense sand, gravel ... & $>50$ & $85-100$ & - & $>700$ \\
\hline & 3 Hard clay and silty clay ... & $>32$ & - & $>400$ & $>700$ \\
\hline \multirow[t]{3}{*}{ B } & $\begin{array}{l}1 \text { Soft volcanic rocks such as tuff and agglomerate, weathered cemented } \\
\text { sedimentary rocks with planes of discontinuity ...... }\end{array}$ & - & - & $500-1000$ & $700-1000$ \\
\hline & 2 Dense sand, gravel ........... & $30-50$ & $65-85$ & - & $400-700$ \\
\hline & 3 Very stiff clay, silty clay ... & $16-32$ & - & $200-400$ & $300-700$ \\
\hline \multirow[t]{3}{*}{$\mathrm{C}$} & $\begin{array}{l}1 \text { Highly weathered soft metamorphic rocks and cemented sedimentary } \\
\text { rocks with planes of discontinuity }\end{array}$ & - & - & $<500$ & $400-700$ \\
\hline & 2 Medium dense sand and gravel .... & $10-30$ & $35-65$ & - & $200-400$ \\
\hline & 3 Stiff clay and silty clay ...... & $8-16$ & - & $100-200$ & $200-300$ \\
\hline \multirow[t]{3}{*}{$\mathrm{D}$} & 1 Soft, deep alluvial layers with high ground water level & - & - & - & $<200$ \\
\hline & 2 Loose sand ...... & $<10$ & $<35$ & - & $<200$ \\
\hline & 3 Soft clay and silty clay ..... . & $<8$ & - & $<100$ & $<200$ \\
\hline
\end{tabular}

Table 4

Various parameters from selected records in station 3513.

\begin{tabular}{|c|c|c|c|c|c|c|c|c|c|c|}
\hline \multirow[t]{2}{*}{ Event } & \multirow[t]{2}{*}{ Date } & \multirow{2}{*}{$\frac{\text { Hour }}{(\mathrm{UTC}+3)}$} & \multicolumn{2}{|c|}{ Magnitude } & \multirow{2}{*}{$\frac{\text { PGA }}{(\mathrm{g})}$} & \multirow{2}{*}{$\frac{\mathrm{PGV}}{(\mathrm{m} / \mathrm{s})}$} & \multirow{2}{*}{$\frac{\text { PGD }}{(\mathrm{m})}$} & \multirow{2}{*}{$\frac{\text { PSA (0.3s) }}{(\mathrm{g})}$} & \multirow{2}{*}{$\frac{\text { PSA (1.0s) }}{(\mathrm{g})}$} & \multirow{2}{*}{$\frac{\text { PSA (3.0s) }}{(\mathrm{g})}$} \\
\hline & & & $\mathrm{M}_{\mathrm{L}}$ & $\mathrm{M}_{\mathrm{W}}$ & & & & & & \\
\hline 20201030115124 & 30102020 & $14: 51: 24$ & & 6.6 & 0.10834 & 0.17107 & 0.03152 & 0.28607 & 0.34677 & 0.03108 \\
\hline 20201030115353 & 30102020 & $14: 53: 53$ & 4.7 & & 0.01136 & 0.00720 & 0.00582 & 0.04005 & 0.00464 & 0.00179 \\
\hline 20201030115501 & 30102020 & 14:55:01 & 4.1 & & 0.00201 & 0.00221 & 0.00176 & 0.00641 & 0.00108 & 0.00117 \\
\hline 20201030115601 & 30102020 & 14:56:01 & 4.1 & & 0.00534 & 0.00208 & 0.00137 & 0.01792 & 0.00127 & 0.00044 \\
\hline 20201030115929 & 30102020 & 14:59:29 & 4.1 & & 0.00148 & 0.00093 & 0.00055 & 0.00290 & 0.00055 & 0.00017 \\
\hline 20201030120137 & 30102020 & 15:01:37 & & 4.8 & 0.00146 & 0.00125 & 0.00022 & 0.00600 & 0.00124 & 0.00007 \\
\hline 20201030121909 & 30102020 & $15: 19: 09$ & & 4.7 & 0.00093 & 0.00066 & 0.00013 & 0.00254 & 0.00076 & 0.00007 \\
\hline 20201030122951 & 30102020 & $15: 29: 51$ & & 4.2 & 0.00143 & 0.00075 & 0.00007 & 0.00408 & 0.00051 & 0.00007 \\
\hline 20201030130042 & 30102020 & $16: 00: 42$ & & 4.8 & 0.00572 & 0.00284 & 0.00040 & 0.01691 & 0.00350 & 0.00024 \\
\hline 20201030151456 & 30102020 & $18: 14: 56$ & & 5.1 & 0.00650 & 0.00620 & 0.00097 & 0.01618 & 0.00770 & 0.00078 \\
\hline 20201030152434 & 30102020 & $18: 24: 34$ & & 4.0 & 0.00105 & 0.00059 & 0.00007 & 0.00307 & 0.00071 & 0.00004 \\
\hline 20201030214625 & 31102020 & $00: 46: 25$ & 4.0 & & 0.00071 & 0.00056 & 0.00010 & 0.00188 & 0.00073 & 0.00006 \\
\hline 20201030233325 & 31102020 & 02:33:25 & & 4.0 & 0.00060 & 0.00052 & 0.00007 & 0.00190 & 0.00060 & 0.00004 \\
\hline 20201031002051 & 31102020 & 03:20:51 & & 4.1 & 0.00083 & 0.00037 & 0.00005 & 0.00146 & 0.00045 & 0.00003 \\
\hline 20201031014031 & 31102020 & $04: 40: 31$ & & 4.2 & 0.00038 & 0.00033 & 0.00007 & 0.00099 & 0.00084 & 0.00006 \\
\hline 20201031021027 & 31102020 & 05:10:27 & & 4.3 & 0.00147 & 0.00080 & 0.00005 & 0.00540 & 0.00028 & 0.00004 \\
\hline 20201031053130 & 31102020 & 08:31:30 & & 5.0 & 0.00708 & 0.00548 & 0.00063 & 0.01925 & 0.00374 & 0.00100 \\
\hline 20201031084151 & 31102020 & $11: 41: 51$ & & 4.0 & 0.00118 & 0.00069 & 0.00005 & 0.00464 & 0.00038 & 0.00004 \\
\hline 20201031123703 & 31102020 & $15: 37: 03$ & 4.0 & & 0.00131 & 0.00061 & 0.00005 & 0.00248 & 0.00047 & 0.00003 \\
\hline 20201101070513 & 1112020 & $10: 05: 13$ & 4.5 & & 0.00322 & 0.00210 & 0.00023 & 0.00727 & 0.00158 & 0.00011 \\
\hline 20201101073307 & 1112020 & 10:33:07 & 4.2 & & 0.00121 & 0.00104 & 0.00023 & 0.00267 & 0.00139 & 0.00021 \\
\hline 20201101125703 & 1112020 & $15: 57: 03$ & 4.2 & & 0.00120 & 0.00106 & 0.00014 & 0.00221 & 0.00149 & 0.00008 \\
\hline 20201102191640 & 2112020 & $22: 16: 40$ & & 4.2 & 0.00057 & 0.00034 & 0.00007 & 0.00183 & 0.00054 & 0.00007 \\
\hline 20201111064945 & 11112020 & 09:49:45 & 4.8 & & 0.00646 & 0.00400 & 0.00041 & 0.02098 & 0.00407 & 0.00020 \\
\hline
\end{tabular}

Table 5

Various parameters from selected records in station 3514.

\begin{tabular}{|c|c|c|c|c|c|c|c|c|c|c|}
\hline \multirow[t]{2}{*}{ Event } & \multirow[t]{2}{*}{ Date } & \multirow{2}{*}{$\frac{\text { Hour }}{(\mathrm{UTC}+3)}$} & \multicolumn{2}{|c|}{ Magnitude } & \multirow{2}{*}{$\frac{\text { PGA }}{(\mathrm{g})}$} & \multirow{2}{*}{$\frac{P G V}{(m / s)}$} & \multirow{2}{*}{$\frac{\text { PGD }}{(\mathrm{m})}$} & \multirow{2}{*}{$\frac{\operatorname{PSA}(0.3 \mathrm{~s})}{(\mathrm{g})}$} & \multirow{2}{*}{$\frac{\text { PSA (1.0s) }}{(\mathrm{g})}$} & \multirow{2}{*}{$\frac{\text { PSA (3.0s) }}{(\mathrm{g})}$} \\
\hline & & & $\mathrm{M}_{\mathrm{L}}$ & $\mathrm{M}_{\mathrm{W}}$ & & & & & & \\
\hline 20201030115124 & 30102020 & $14: 51: 24$ & & 6.6 & 0.05711 & 0.06412 & 0.01444 & 0.09964 & 0.12254 & 0.00840 \\
\hline 20201030115353 & 30102020 & $14: 53: 53$ & 4.7 & & 0.00521 & 0.00419 & 0.00328 & 0.02322 & 0.00146 & 0.00094 \\
\hline 20201030115601 & 30102020 & 14:56:01 & 4.1 & & 0.00187 & 0.00115 & 0.00105 & 0.00694 & 0.00048 & 0.00024 \\
\hline 20201030115929 & 30102020 & $14: 59: 29$ & 4.1 & & 0.00088 & 0.00048 & 0.00049 & 0.00177 & 0.00018 & 0.00009 \\
\hline 20201030120137 & 30102020 & $15: 01: 37$ & & 4.8 & 0.00072 & 0.00046 & 0.00020 & 0.00255 & 0.00036 & 0.00004 \\
\hline 20201030130042 & 30102020 & $16: 00: 42$ & & 4.8 & 0.00352 & 0.00167 & 0.00016 & 0.01320 & 0.00116 & 0.00011 \\
\hline 20201030151456 & 30102020 & $18: 14: 56$ & & 5.1 & 0.00358 & 0.00297 & 0.00041 & 0.00966 & 0.00269 & 0.00031 \\
\hline 20201030152434 & 30102020 & $18: 24: 34$ & & 4.0 & 0.00070 & 0.00040 & 0.00003 & 0.00183 & 0.00022 & 0.00001 \\
\hline 20201030214625 & 31102020 & $00: 46: 25$ & 4.0 & & 0.00045 & 0.00019 & 0.00002 & 0.00081 & 0.00015 & 0.00001 \\
\hline 20201030233325 & 31102020 & $02: 33: 25$ & & 4.0 & 0.00038 & 0.00023 & 0.00003 & 0.00082 & 0.00021 & 0.00001 \\
\hline 20201031002051 & 31102020 & 03:20:51 & & 4.1 & 0.00028 & 0.00012 & 0.00002 & 0.00063 & 0.00014 & 0.00001 \\
\hline 20201031014031 & 31102020 & 04:40:31 & & 4.2 & 0.00020 & 0.00016 & 0.00003 & 0.00042 & 0.00022 & 0.00002 \\
\hline 20201031021027 & 31102020 & $05: 10: 27$ & & 4.3 & 0.00058 & 0.00022 & 0.00002 & 0.00196 & 0.00010 & 0.00002 \\
\hline 20201031053130 & 31102020 & 08:31:30 & & 5.0 & 0.00376 & 0.00187 & 0.00034 & 0.01603 & 0.00114 & 0.00036 \\
\hline 20201111064945 & 11112020 & $09: 49: 45$ & 4.8 & & 0.00227 & 0.00144 & 0.00017 & 0.00579 & 0.00123 & 0.00008 \\
\hline
\end{tabular}



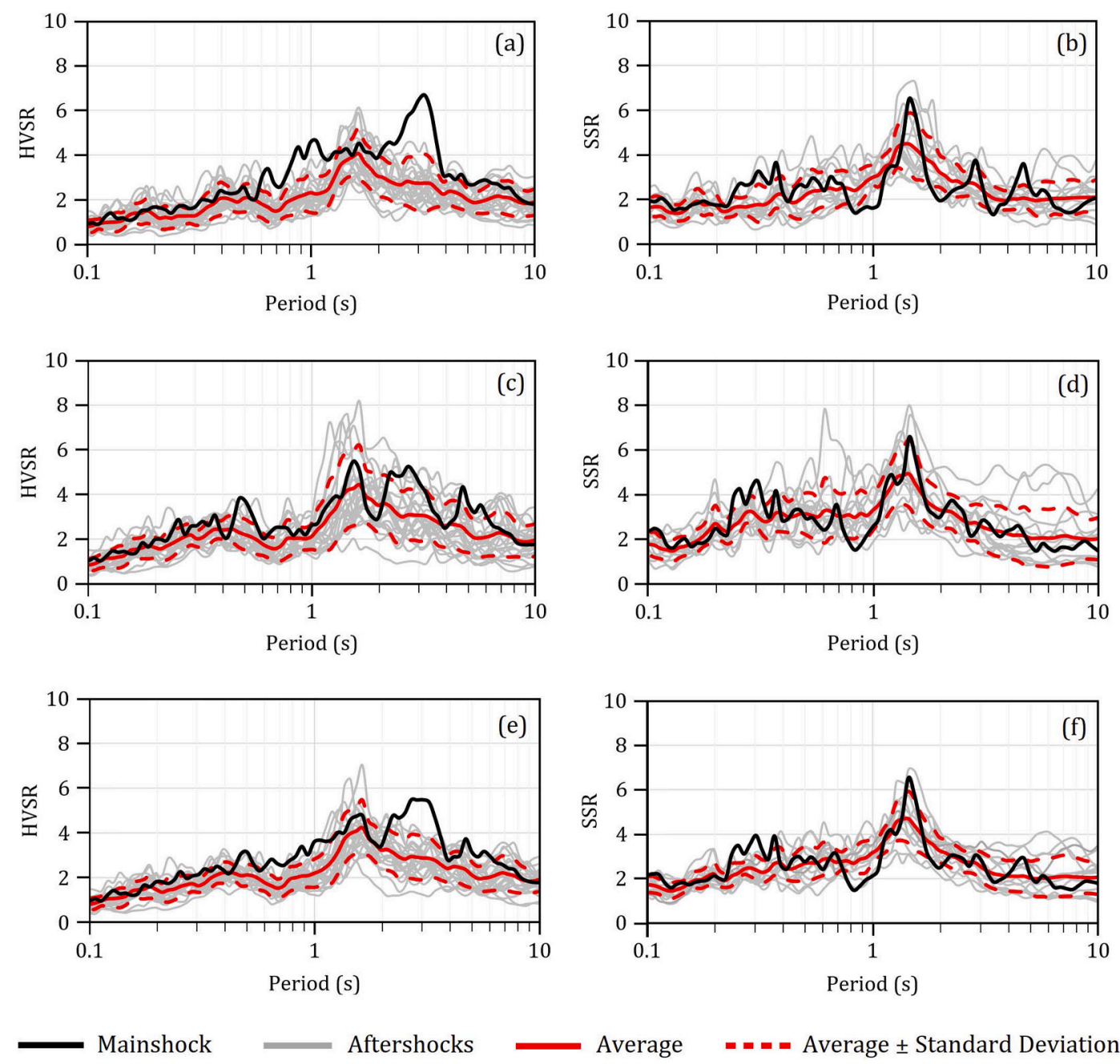

Average $=-\mathbf{m}=$ Average \pm Standard Deviation

Fig. 14. HVSR and SSR of selected earthquake records. Spectral ratios are in E-W direction (HVSR (a) and SSR (b)), N-S direction ((HVSR (c) and SSR (d)) and arithmetic average of directions (HVSR (e) and SSR (f)).

Table 6

Predominant period of soil and soil amplification values from HVSR and SSR.

\begin{tabular}{|c|c|c|c|c|c|c|c|}
\hline \multirow[t]{2}{*}{ Event } & \multirow[t]{2}{*}{ Method } & \multicolumn{3}{|c|}{ Predominant Period of Soil } & \multicolumn{3}{|c|}{ Soil Amplification } \\
\hline & & $\begin{array}{l}\text { E-W } \\
\text { Direction }\end{array}$ & $\begin{array}{l}\mathrm{N}-\mathrm{S} \\
\text { Direction }\end{array}$ & $\begin{array}{l}\text { Arithmetic } \\
\text { Mean of Directions }\end{array}$ & $\begin{array}{l}\text { E-W } \\
\text { Direction }\end{array}$ & $\begin{array}{l}\mathrm{N}-\mathrm{S} \\
\text { Direction }\end{array}$ & $\begin{array}{l}\text { Arithmetic } \\
\text { Mean of Directions }\end{array}$ \\
\hline \multirow[t]{2}{*}{ Mainshock } & SSR & $1.44 \mathrm{~s}$ & $1.44 \mathrm{~s}$ & $1.44 \mathrm{~s}$ & 6.50 & 6.58 & 6.54 \\
\hline & HVSR & $3.24 \mathrm{~s}$ & $1.54 \mathrm{~s}$ & $3.04 \mathrm{~s}$ & 6.68 & 5.49 & 5.48 \\
\hline \multirow[t]{2}{*}{ Average of selected recordings for each method } & SSR & $1.44 \mathrm{~s}$ & $1.44 \mathrm{~s}$ & $1.44 \mathrm{~s}$ & 4.49 & 4.91 & 4.70 \\
\hline & HVSR & $1.63 \mathrm{~s}$ & $1.63 \mathrm{~s}$ & $1.63 \mathrm{~s}$ & 4.08 & 4.43 & 4.25 \\
\hline
\end{tabular}

Table 7

Evaluation of resonance potential of buildings in Manavkuyu Neighborhood depending upon number of storeys according to Stanko et al. [41].

\begin{tabular}{lllll}
\hline $\begin{array}{l}\text { Structural Vibration } \\
\text { Period }\end{array}$ & $\begin{array}{l}\text { Natural } \\
\text { Vibration } \\
\text { Period (s) }\end{array}$ & $\begin{array}{l}\text { Number of } \\
\text { storeys }\end{array}$ & $\begin{array}{l}\text { Resonance } \\
\text { Potential } \\
\text { Ratio (\%) }\end{array}$ & $\begin{array}{l}\text { Resonance } \\
\text { Potential }\end{array}$ \\
\hline $\begin{array}{l}\text { Shorter than } \\
\text { predominant period }\end{array}$ & 0.1 to 1.0 & 1 to 10 & $\begin{array}{l}93.1 \text { to } \\
30.6\end{array}$ & Low \\
$\quad$ of soil & 1.1 to 1.2 & 11 to 12 & $\begin{array}{l}23.6 \text { to } \\
16.7\end{array}$ & Medium \\
& & & 9.7 to 0.0 & High \\
& 1.3 to 1.5 & 13 to 15 & 0.0 to 10.4 & High \\
& 1.6 to 1.8 & 16 to 18 & 16.6 to & Medium \\
Longer than & 1.9 to 2.0 & 19 to 20 & & Low \\
$\quad$ predominant period & & & $>22.7$ & \\
$\quad>2.0$ & $>20$ & & &
\end{tabular}

composed of the conventional reinforced concrete (RC) type of structures and the damaged structures are dominantly RC type moment resisting frames or shear wall structural systems. Therefore, based on the visual inspections by the authors, this section is reserved for the structural assessment of the observed damage in RC buildings in the context of the presented reconnaissance study. As compatible with the reported observations after the previous severe earthquakes in Turkey (such as Kocaeli and Düzce 1999, and Van 2011 earthquakes), the first impressions by the authors point out some typical damage and failure profiles for the observed structures in these locations. These damage profiles can be typically classified as:

- Failures due to the defects in the concrete works, and reinforcement detailing 


\begin{tabular}{|c|c|c|c|}
\hline Size of strain $(\gamma)$ & $10^{-6}$ & $10^{-4}$ & $10^{-2}$ \\
\hline Phenomena & Wave, vibration & Crack, settlement & Landslide, Soil Compaction, Liquefaction \\
\hline Dynamic properties & Elasticity & Elasto-plasticity & Collapse \\
\hline
\end{tabular}

Fig. 15. Strain dependence of dynamic properties of soil (Reproduced from [45]).

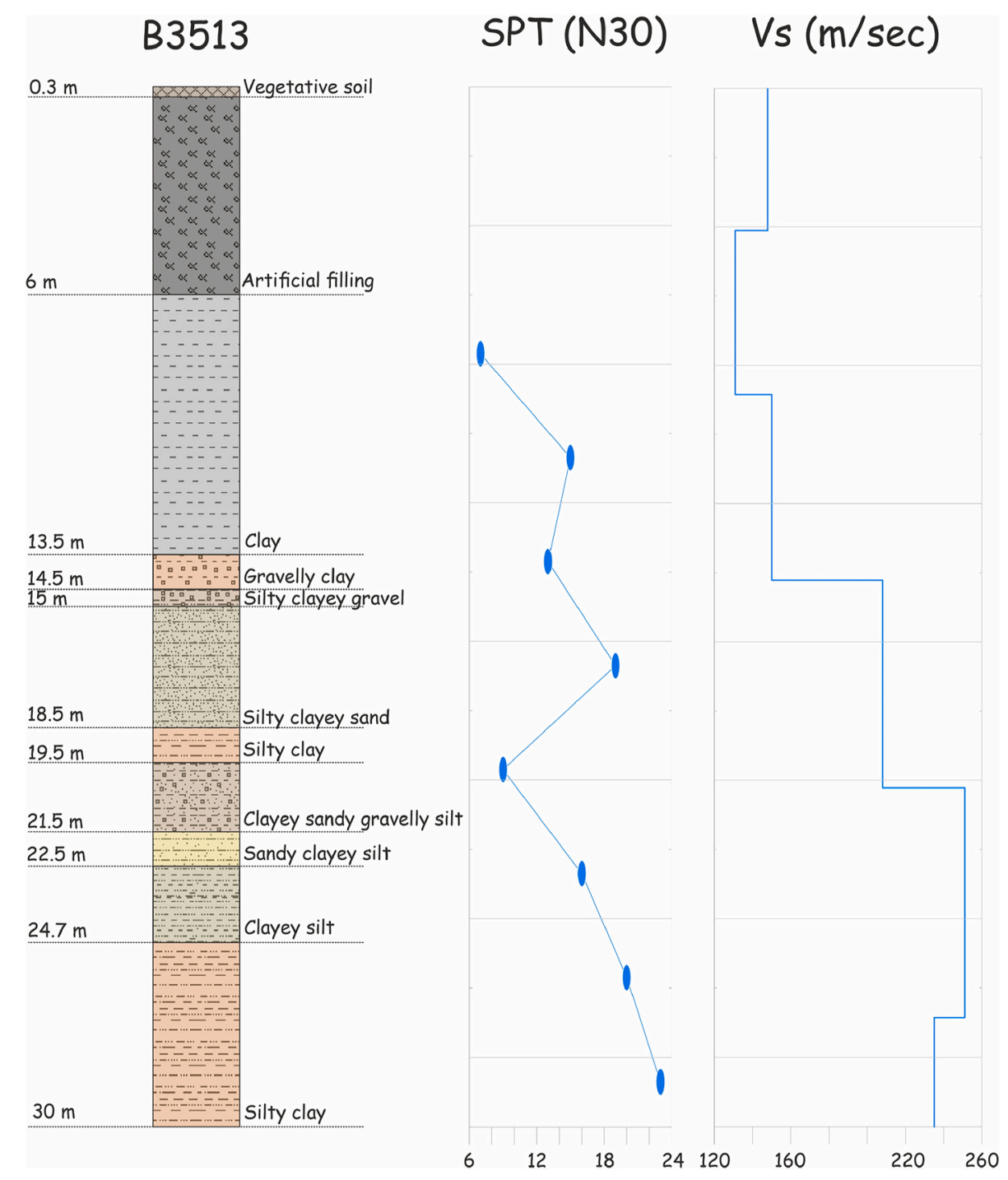

Fig. 16. Soil properties beneath station 3513 (Reproduced from [12]).

- Damage at the beam-column joints

- Soft story failures and short-column damage

- Frame irregularities and heavy overhangs

Concerning geotechnical issues, effects including foundation failures, observation of liquefaction-based soil deformation, rockfalls and landslides, damage in subsurface or buried structures were not reported in the boundaries of Izmir city [38]. For this reason, the reported damage in this study is limited with the structural aspects.

\subsection{Failures due to the defects in the concrete works, and reinforcement detailing}

A considerable majority of the available structures in Izmir have been built before 1998 when a comprehensive building design code against earthquake effects was first released. On the other hand, the usage of ready-mixed concrete and ribbed steel reinforcements, which may highly influence the performance of the RC members, are commonly used since late 90 's. In the recent earthquake event, serious damage was observed in the reinforced concrete structures due to these drawbacks. For example, the lack of workmanship in the conventional concrete works caused some serious segregation problems in crucial members (Fig. 19a), leading to severe local damage. In addition, serious compression failures were also observed due to inadequate and unribbed transverse reinforcement steel with improper hook detailing (Fig. 19b). Although the current design code allows use of a maximum spacing of $15 \mathrm{~cm}$ for transverse reinforcement within the confinement zone, some of the old buildings do not satisfy this requirement (Fig. 19c). These types of damage are less frequently observed at structures built after 2007. Therefore, the low workmanship quality and improper detailing 
Table 8

Dynamic properties $\left(\mathrm{V}_{\max }, \gamma_{\mathrm{eff}}\right)$ for top $30 \mathrm{~m}$ soil profile beneath 3513 Station during $M_{w}=7.0$ Samos Earthquake.

\begin{tabular}{|c|c|c|c|c|c|c|}
\hline & $\begin{array}{l}3513 \mathrm{EW} \\
\mathrm{V}_{\max }(\mathrm{m} / \\
\mathrm{sec})\end{array}$ & $\begin{array}{l}3513 \mathrm{NS} \\
\mathrm{V}_{\max }(\mathrm{m} / \\
\mathrm{sec})\end{array}$ & $\begin{array}{l}\mathrm{V}_{\mathrm{Sl}} \\
(\mathrm{m} / \\
\mathrm{sec})\end{array}$ & $\begin{array}{l}\text { Thickness } \\
\text { (m) }\end{array}$ & $\begin{array}{l}\gamma_{\text {eff }} \\
(\mathrm{EW}) \\
\times \\
10^{-4}\end{array}$ & $\begin{array}{l}\gamma_{\text {eff }} \\
(\mathrm{NS}) \\
\times \\
10^{-4}\end{array}$ \\
\hline $\begin{array}{l}\text { Layer } \\
1\end{array}$ & 0.14159 & 0.17174 & 148 & 4.107 & $3.83^{\mathrm{a}}$ & $4.64^{\mathrm{a}}$ \\
\hline $\begin{array}{c}\text { Layer } \\
2\end{array}$ & 0.13764 & 0.16769 & 131 & 4.739 & $4.20^{\mathrm{a}}$ & $5.12^{\mathrm{a}}$ \\
\hline $\begin{array}{c}\text { Layer } \\
3\end{array}$ & 0.12633 & 0.14858 & 150 & 5.371 & $3.37^{\mathrm{a}}$ & $3.96^{\mathrm{a}}$ \\
\hline $\begin{array}{c}\text { Layer } \\
4\end{array}$ & 0.11135 & 0.1227 & 208 & 6.003 & 2.14 & 2.36 \\
\hline $\begin{array}{l}\text { Layer } \\
5\end{array}$ & 0.10185 & 0.10364 & 251 & 6.635 & 1.62 & 1.65 \\
\hline $\begin{array}{c}\text { Layer } \\
6\end{array}$ & 0.09421 & 0.10009 & 235 & 3.146 & 1.60 & 1.70 \\
\hline
\end{tabular}

${ }^{\text {a }}$ Greater than threshold of nonlinear ground response.

in the reinforced concrete members arise as a challenging problem for the earthquake resistance of older buildings.

\subsection{Damage at the beam-column joints}

Design of beam column joints with proper sizing and reinforcement detailing arises as an important problem for reinforced concrete structures, which might experience severe earthquake events. Design specifications after [36] urges to increase the ductility demand of beam-column joints (and adequately high shear strength) with proper detailing for strong column-weak beam behaviour. However, field observations based on the recent previous earthquake events (such as Kocaeli, and Duzce 1999, Erciş 2011, and Izmir 2020) experienced in Turkey reveal that these obligations are not perfectly satisfied in practice. In the context of this study, a considerable weak column-strong beam damage observed in the Bayrakli District, after the Samos 2020 Earthquake. During the assessment, the joint damage including weak-column strong beam and shear failure have been attempted to be identified by visual inspections (Fig. 20a). These inspections indicate that no single type of damage purely occurred especially in the relatively old structures which were built before the 2000's. Generally, a sort of combination of shear and weak column-strong beam damage were observed. Although the weak column-strong beam damage are defined based on the flexural capacities of those elements with adequate shear capacity, some observations reveal that these failures may be experienced together (Fig. 20b).

\subsection{Soft story failures and short-column damage}

As a general intention, in many buildings, first stories are reserved as non-residential areas for commercial use. Therefore, soft story irregularities may be inevitably observed in such kinds of buildings in which the story height is relatively large and infill walls are fully or partially removed. Although the code provisions in Turkey forces the designers to consider the soft story effects, some of older buildings still suffer from this drawback. This case was also observed after the recent earthquake (Fig. 21). Similarly, due to architectural and commercial concerns, short column damage was frequently encountered in the Bornova, Bayrakli, and Konak Districts because of partial openings on the infill walls (Fig. 22).

\subsection{Frame irregularities and heavy overhangs}

Due to architectural concerns, the use of heavy overhangs is widely seen even in young buildings built according to the latest version of the design codes. In relation to use of overhangs, the continuity of structural resisting systems may significantly disrupt, leading to a dramatic loss of load resisting capacity. Moreover, in case of non-optimal proportion is used in the design procedure of heavy or excessive overhangs with frame irregularities, large torsional effects may be indispensably experienced due to the change in centre of mass, when this issue is not properly considered in the design procedure. In the context of this reconnaissance study, heavy shear damage in the infill walls at the outer fronts of the buildings was frequently observed not only in Bayrakli, Bornova and Karsiyaka districts but also in the other regions of Izmir (Fig. 23).

\section{Conclusions}

This study presents a comprehensive assessment based on the observations from a reconnaissance study accompanied by detailed geological, geophysical and geotechnical assessment of damage

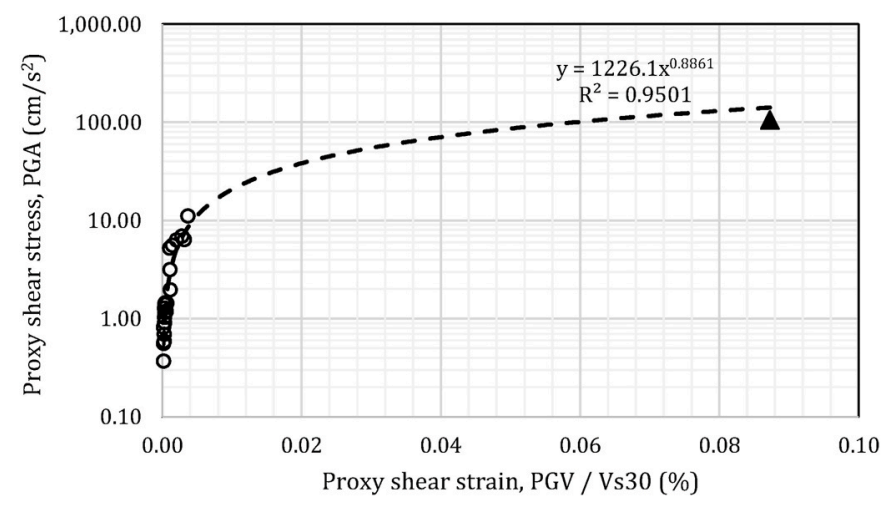

Fig. 18. Relationship between PGA (proxy shear stress) and PGV/Vs (proxy shear strain) belonging to main shock and aftershocks at 3513 Station.

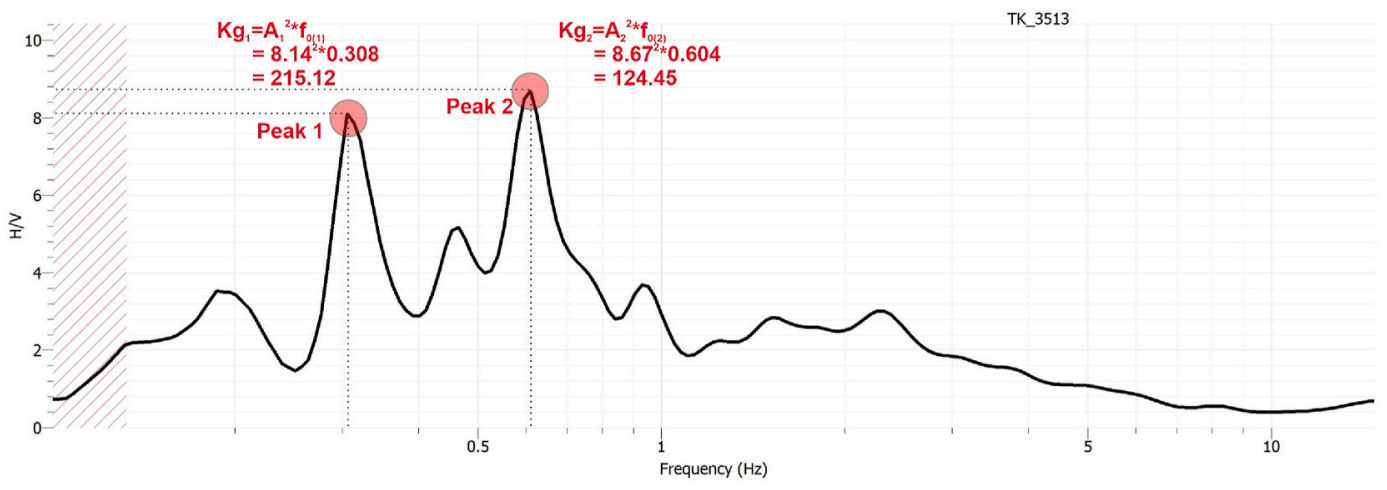

Fig. 17. QTS of 3513 station $\left(\mathrm{M}_{\mathrm{W}}=7.0\right.$ samos earthquake) and $\mathrm{K}_{\mathrm{g}}$ values. 
a)

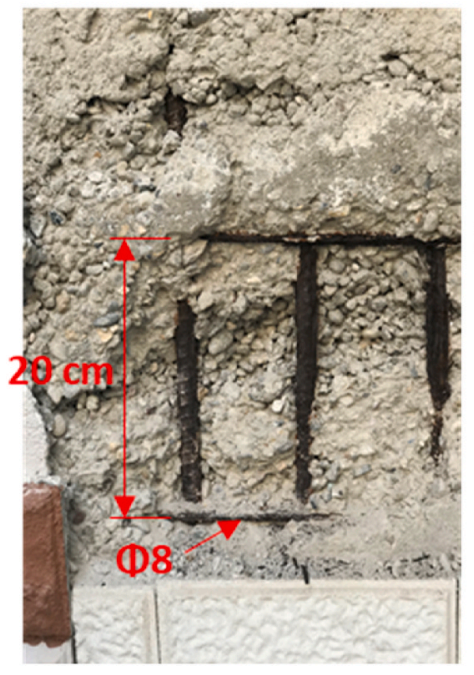

b)

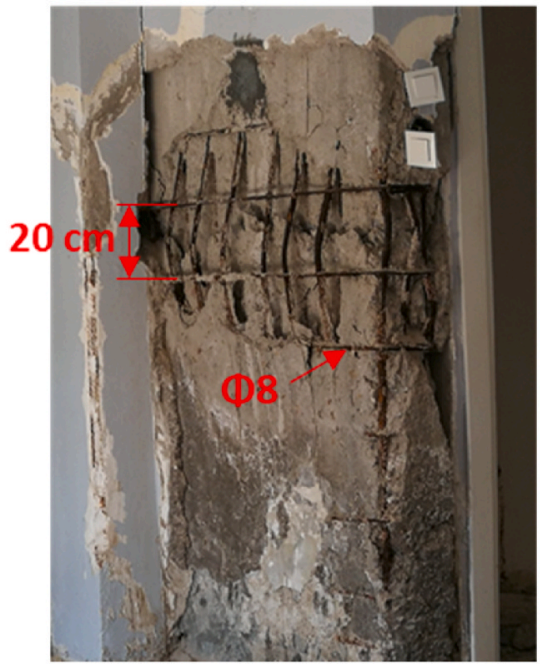

c)

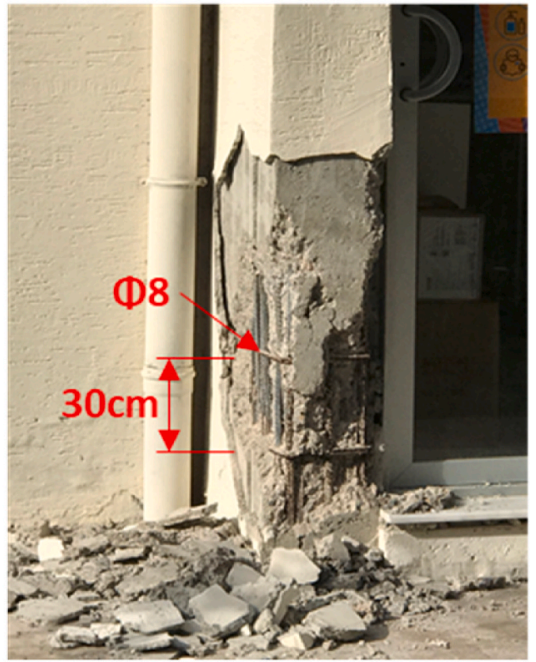

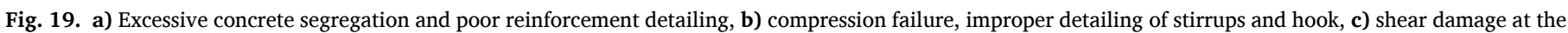
column due to the insufficient stirrup spacing in the confinement zone.

a)

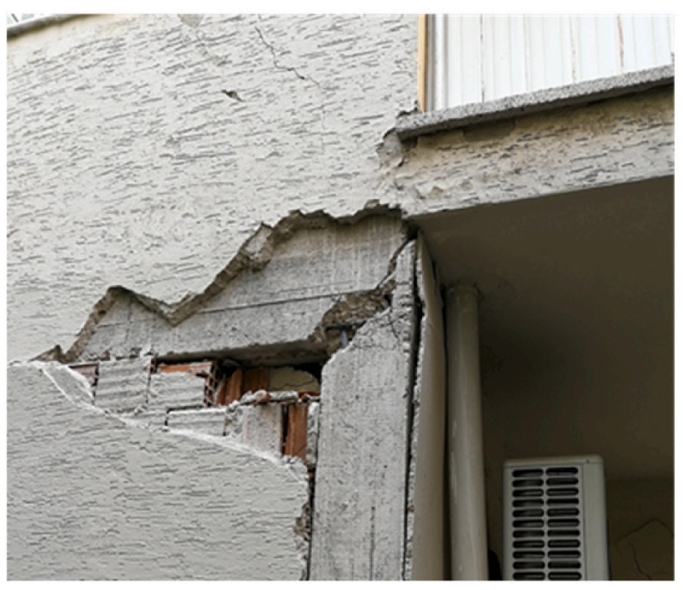

b)

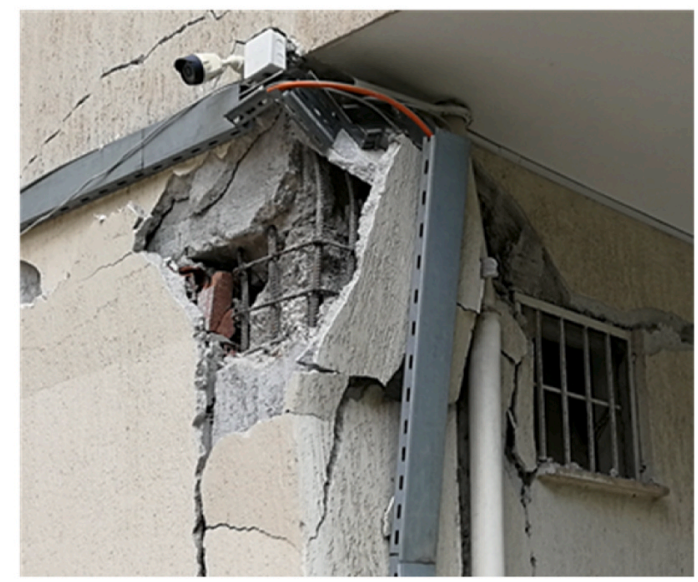

Fig. 20. a) Weak column-strong beam damage, b) Combined weak column-strong beam and shear failure.

occurred in Bayrakli District after October 30, 2020 Samos earthquake. Fundamental results are enlisted below:

- Considering the thick alluvial unit and its geometric formation, it can be concluded that Bornova Plain may be subjected to both ground amplification and basin effects. This observation can also be considered as the main reason for the extension in the constant acceleration region in the acceleration response spectra.

- Local site effects, especially the resonance phenomena, possibly affected the seismic response of structures. Strain dependent and cycle dependent degradation of stiffness due to seismic excitation is coupled with an increase in soil damping, which in turn may be responsible for reduction in amplification.

- Based on the evaluated PGA and plotted response spectra, October 2020 Samos earthquake can be considered as a far field earthquake for Izmir city center. Occurrence of a near field earthquake can make it possible to observe extensive structural damage due to the improper design and reinforcement detailing. However, the structural damage observed in the Manavkuyu neighborhood reveal that the structures behaved as if they were affected by a near field earthquake.
- Despite a significant number of heavily damaged and collapsed structures and casualties in the Bayraklı district, the availbe buildings show overall good performance against the earthquake and experience relatively lower damages. The reason for the fact that the damaged structures are mostly encountered in the Bayrakli, Karşıyaka and Bornova districts are considered to stem from the local site effects. Observed structural damage reveal that the older buildings which do not substantially meet the current code requirements are still vulnerable against such kind of earthquake events. In case the local site effects are not accurately included in the design procedure, most of the available buildings may experience serious damage even for the earthquakes with relatively small PGAs with respect to the design values.

- For future research, simplified design procedures should be constituted like resonance potential assessment elaborating the soilstructure interaction effects. In this way, structural design concepts incorporating the resonance and basin effects is viable to use in practice. Moreover, since the last earthquake record seems to be an unusual one (having a relatively low PGA and a wider constant acceleration region), regulations and codes specific to Izmir should be prepared. 
(a)

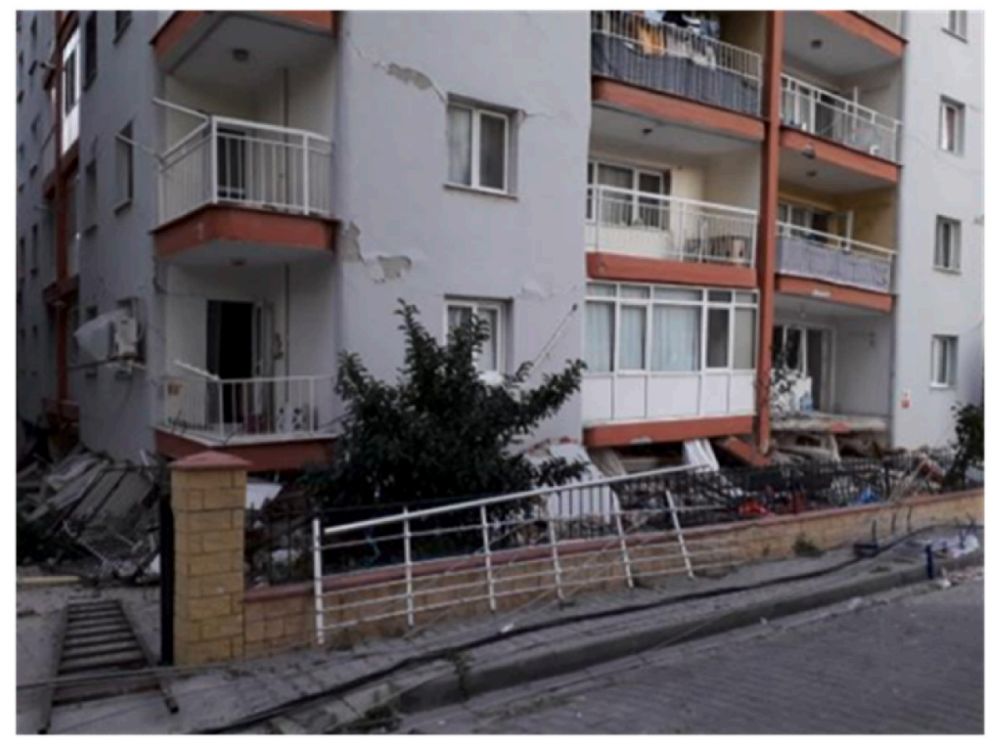

(b)

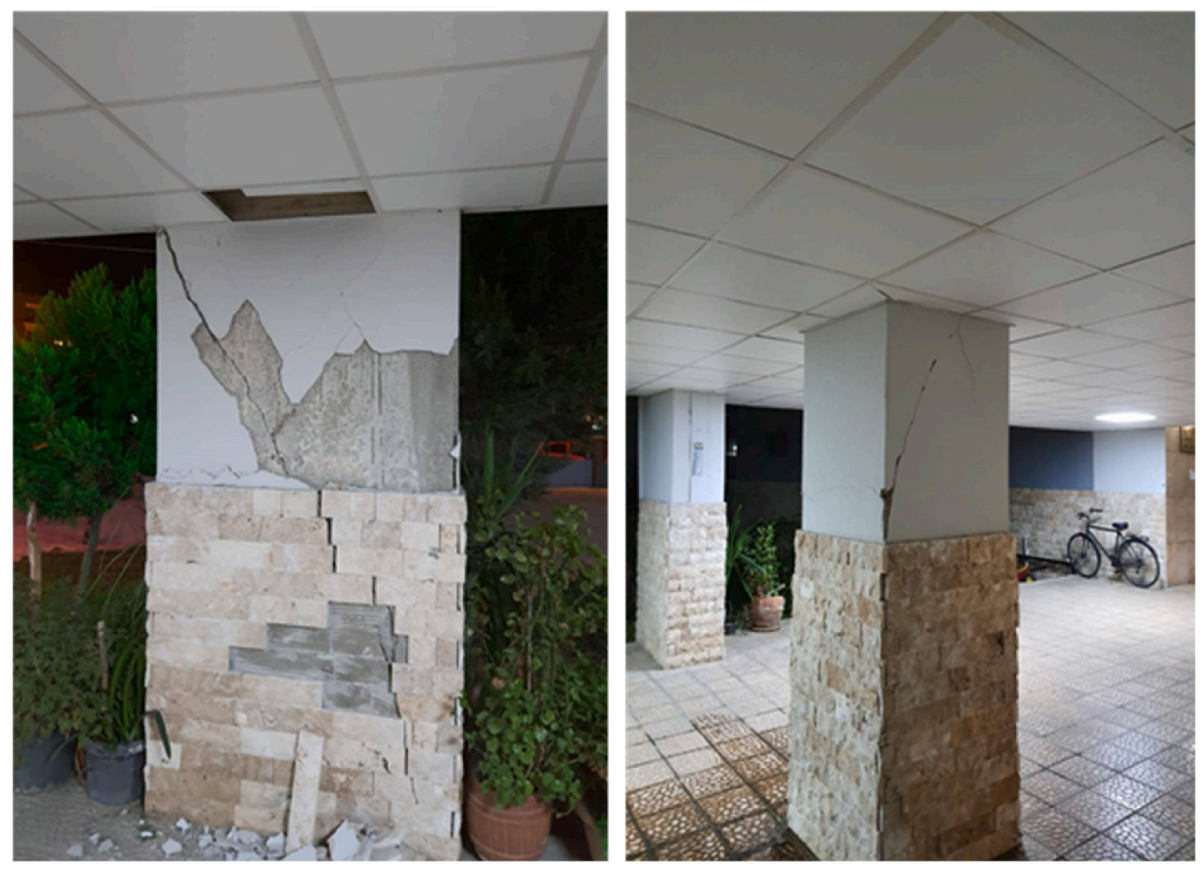

Fig. 21. Views from the observed soft story effect a) First story collapse [21]. b) shear damage. 

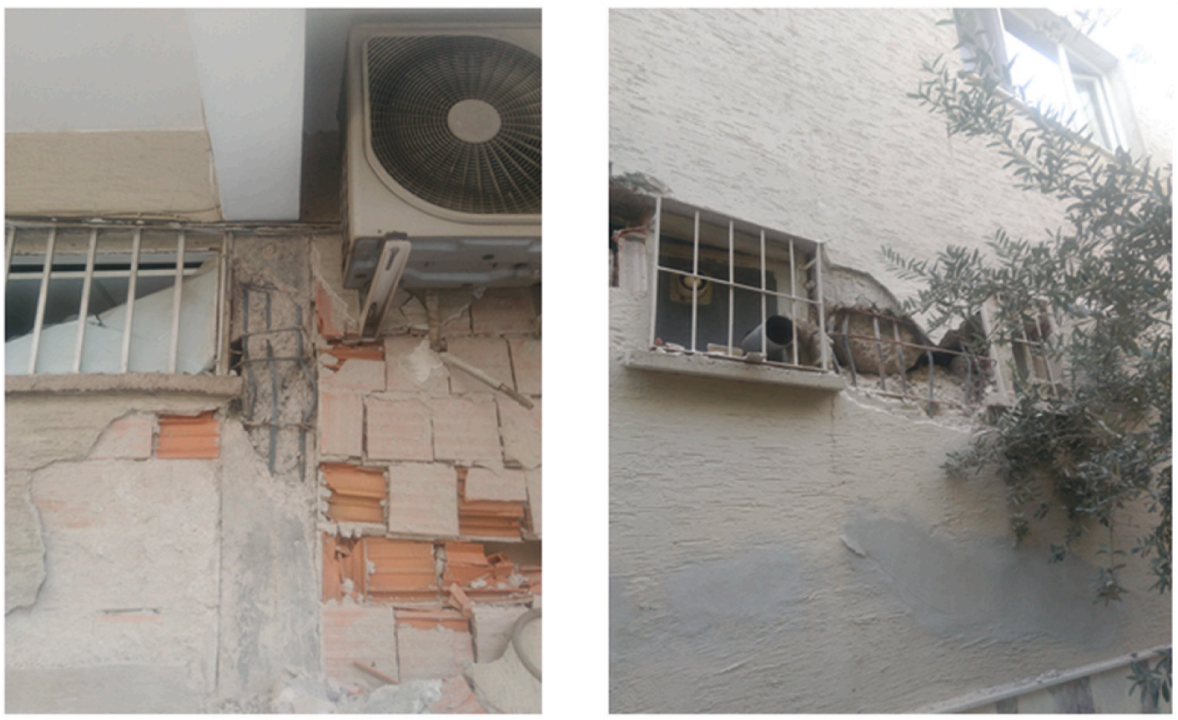

Fig. 22. Observed shear failures due to the short column effect.
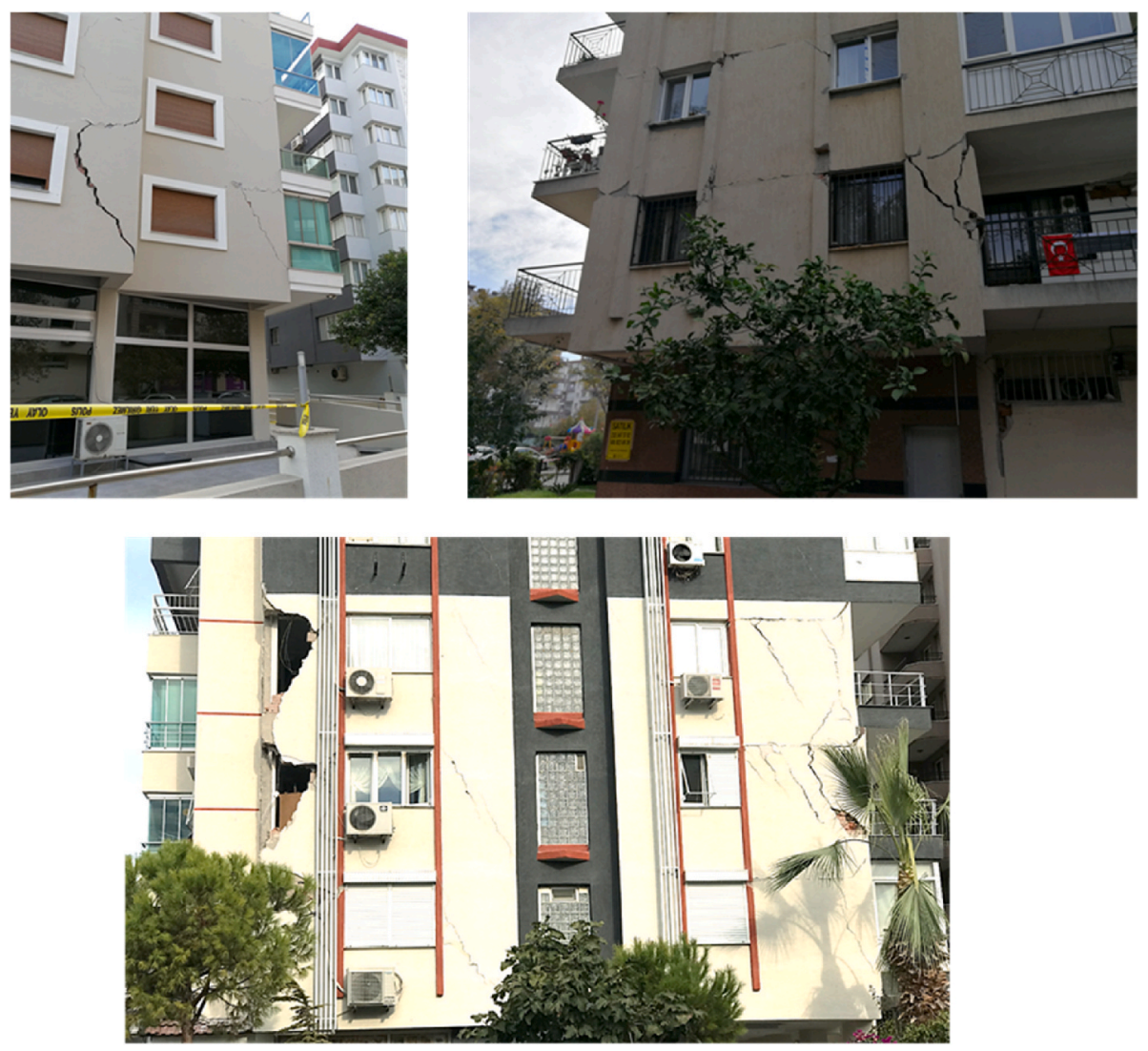

Fig. 23. Observed masonry wall damage due to the heavy overhangs. 


\section{Declaration of competing interest}

The authors declare that they have no known competing financial interests or personal relationships that could have appeared to influence the work reported in this paper.

\section{References}

[1] USGS, 2020. https://earthquake.usgs.gov/earthquakes/eventpage/us7000c7y0/e xecutive (Accessed on 21th of April, 2021).

[2] DAUM, 30 EKiM 2020 (SAMOS) Earthquake (Mw: 6.9) Evaluation Report, 2020, p. 111, pages (In Turkish).

[3] L.W. Bjerrum, T. Lutro, M.B. Sørensen, L. Ottemöller, C. Sari, K. Atakan, "Simulated ground motions with site effects potential evaluated through transfer functions and H/V measurements: case study for Izmir, Turkey", in: Second European Conference on Earthquake Engineering and Seismology, Istanbul, August 25-29, 2014.

[4] L.W. Bjerrum, Ground Motion Simulations for Izmir, Turkey, Based on Earthquake Rupture Scenarios, MSc Thesis, University of Bergen, Norway, 2007, p. 162.

[5] L.W. Bjerrum, K. Atakan, "Scenario based ground motion simulations for assessing the seismic hazard in Izmir, Turkey", in: Proceedings of the 14th World Conference on Earthquake Engineering, Beijing, China, 12-17 October 2008, 2008.

[6] L.W. Bjerrum, M.B. Sørensen, L. Ottemöller, K. Atakan, Sensitivity of ground motions due to input parameter uncertainty: a case study for Izmir, Turkey, J. Seismol. 17 (4) (2013) 1223-1252, https://doi.org/10.1007/s10950-013-93899.

[7] A. Deniz, K.A. Korkmaz, A. Irfanoglu, Probabilistic seismic hazard assessment for İzmir, Turkey, Pure Appl. Geophys. 167 (12) (2010) 1475-1484.

[8] Ö. Emre, S. Özalp, A. Doğan, V. Ozzaksoy, C. Ylldırım, F. Göktaş, Active faults in the vicinity of Izmir and their earthquake potential (in Turkish), Geological Studies Department, General Directorate of Mineral Research and Exploration, Ankara, Turkey. (2005). Report No. 10754.

[9] Erdik, M., Ansal, A., Aydınoğlu, N., Barka, A., Işıkara, A.M., Yüzügüllü, Ö., Avci, J., Özel, O., Biro Y, Birgoren, G., (1999). RADIUS, Izmir earthquake scenario and master plan. Izmir Metropolis Municipality.

[10] Turkish Earthquake Code, TEC-1998, Regulations on Structures Constructed in Disaster Regions, Ministry Of Public Works And Settlement, Ankara, 1998.

[11] Kuruoğlu, M. (2004). Geographical Information System (GIS) based database development and evaluation study for soils of northern coast of Izmir Bay. PhD thesis, Dokuz Eylul University.

[12] TUBITAK 106G159, Modelling of Seismic Behavior of Soils for Safe Design of Buildings against Earthquakes in Izmir Province, Aliaga and Menemen Districts, Research Project Report prepared by Dokuz Eylul University Earthquake Research and Application Centre, Izmir, 2012.

[13] S. Altun, A. Sezer, A.B. Göktepe, A preliminary microzonation study on Northern Coasts of Izmir: investigation of the local soil conditions, Soil Dynam. Earthq. Eng. 39 (2012) 37-49.

[14] A. Sezer, S. Altun, A.B. Goktepe, "Microzonation of liquefaction susceptibility in northern Izmir", in: International Conference of Development of Urban Areas and Geotechnical Engineering, Saint Petersburg, Russia, 16-19 June, 2008.

[15] Bard P-Y, and the SESAME Project Participants, Guidelines for the Implementation of the H/V Spectral Ratio Technique on Ambient Vibrations: Measurements, Processing and Interpretation, SESAME Project Report, Universite Joseph Fourier, Grenoble, France, 2004, p. 50.

[16] J.-L. Chatelain, B. Guillier, F. Cara, A.-M. Duval, K. Atakan, P.-Y. Bard, the WP02 SESAME Team, Evaluation of the influence of experimental conditions on $\mathrm{H} / \mathrm{V}$ results from ambient noise recordings, Bull. Earthq. Eng. 6 (1) (2008) 33-74, https://doi.org/10.1007/s10518-007-9040-7.

[17] Ö.C. Özdağ, T. Gönenc, M. Akgün, Dynamic amplification factor concept of soil layers: a case study in Izmir (Western Anatolia), Arabian Journal of Geosciences 8 (11) (2015) 10093-10104.

[18] A. Tunçel, Ö.C. Özdağ, E. Pamuk, M. Akgün, Mikrotremor verisi kullanılarak zeminlerin dinamik büyütme faktörü değerlerinin hesaplanmass: Izmir (Kuzey) örneği, Journal of the Faculty of Engineering \& Architecture of Gazi University 34 (1) (2019) (In Turkish).

[19] B. Guillier, K. Atakan, J.L. Chatelain, J. Havskov, M. Ohrnberger, F. Cara, A. Duval, S. Zacharopoulos, P. Teves-Costa, Influence of instruments on the H/V spectral ratios of ambient vibrations, Bull. Earthq. Eng. 6 (1) (2008) 3-31.

[20] F. De Luca, G. Woods, C. Galasso, D. D’Ayala, RC infilled building performance against the evidence of the 2016 EEFIT Central Italy post-earthquake reconnaissance mission: empirical fragilities and comparison with the FAST method, Bull. Earthq. Eng. 16 (7) (2018) 2943-2969, https://doi.org/10.1007/ s10518-017-0289-1.

[21] AFAD, "Report for October 30, $2020 \mathrm{M}_{\mathrm{w}}=6.6$ Samos Island Earthquake (Off the Coast of Izmir Seferihisar) ", Earthquake Report, Minister of Internal Affairs of the Republic of Turkey, 2020 (in Turkish).

[22] C. Kincal, Engineering Geological Evaluation of the Geological Units Exposed in Inner Bay Area (Izmir)'s Vicinity Using Geographical Information Systems and Remote Sensing, Ph.D. Thesis, Izmir, 2005, p. 342 (In Turkish).

[23] B. Erdoğan, D. Altıner, T. Güngör, S. Özer, Stratigraphy of Karaburun peninsula, Bull. Min. Res. Exp. 111 (111) (1990) 1-20.

[24] M.Y. Koca, C. Kincal, Abandoned stone quarries in and around the Izmir city centre and their geo-environmental impacts-Turkey, Eng. Geol. 75 (2004) 49-67.
[25] C. Kıncal, A. Aygün, M.Y. Koca, Landslide susceptibility assessment in the Izmir (West Anatolia, Turkey) city center and its near vicinity by the logistic regression method, Environmental Earth Sciences 59 (2009) 745-756.

[26] A. Akgun, C. Kincal, B. Pradhan, Application of remote sensing data and GIS for landslide risk assessment as an environmental threat to Izmir city (west Turkey), Environ. Monit. Assess. 184 (2012) 5453-5470.

[27] M.Y. Koca, C. Kincal, The relationships between the rock material properties and weathering grades of andesitic rocks around Izmir, Turkey, Bull. Eng. Geol. Environ. 75 (2) (2016) 709-734.

[28] Koca, M.Y., Kıncal, C. and Türk, N., 2001. Relations Between the P-wave Velocity and Other Selected Engineering Properties of Andesitic Lavas and Autobreccias in Izmir, Proceedings International Earth Sciences Colloquium on the Aegean Region, IESCA-2000, pp.69-82, Izmir-Turkey.

[29] İ. Kayan, Morpho-tectonic units and alluvial geomorphology of the Izmir and its surroundings, in: Symposium of Earthquake Potential of the Western Anatolia, 2000, p. 103 (In Turkish).

[30] M. Akgün, T. Gönenç, O. Pamukçu, Ş. Özyalın, Ö.C. Özdağ, Integrated Geophysical Methods for the Determination of Engineering Bedrock: Izmir New City Center, Turkish J Geophys, 2013 (in Turkish).

[31] E. Pamuk, M. Akgün, Ö.C. Özdağ, T. Gönenç, 2D soil and engineering-seismic bedrock modeling of eastern part of Izmir inner bay/Turkey, J. Appl. Geophys. 137 (2017) 104-117.

[32] E. Pamuk, T. Gönenç, Ö.C. Özdağ, M. Akgün, 3D bedrock structure of Bornova Plain and its surroundings (Izmir/Western Turkey), Pure Appl. Geophys. 175 (1) (2018) 325-340.

[33] AFAD, Turkish Accelerometric Database and Analysis System, 2021. https://tadas. afad.gov.tr/. (Accessed 21 April 2021).

[34] Turkish Earthquake Code, TEC-2007, Specification for Structures to Be Built in Disaster Areas, Ministry of Public Works and Settlement Government of Republic of Turkey, Ankara, 2007.

[35] Turkish Building Earthquake Code, TEC-2019, AFAD, the Disaster and Emergency Management Authority of Turkey, 2019.

[36] Turkish Earthquake Code, TEC-1975, Ministry of Public Works and Settlement. Specification for Structures to Be Built in Disaster Areas, Government of Republic of Turkey, 1975.

[37] METU/ERC (Middle East Technical University/Earthquake Research Center), A Reconnaissance Study on October $302020 \mathrm{M}_{\mathrm{W}}=6.6$ Samos Island (Off the Coast of Izmir Seferihisar) Earthquake Concerning Seismic and Structural Damage, Earthquake Report, No: ODTÜ/DMAM 2020-03, 2020 (in Turkish).

[38] K.Ö. Çetin, et al., Seismological and Engineering Effects of the M 7.0 Samos Island (Aegean Sea) Earthquake, 2020, https://doi.org/10.18118/G6H088. Report number: GEER-069.

[39] Ministry of Environment and Urbanization, October 30, 2020 Izmir Earthquake, Technical Report, 2020, p. 101 (in Turkish).

[40] W.C. Stone, F.Y. Yokel, M. Celebi, T. Hanks, E.V. Leyendecker, Engineering aspects of the September 19, 1985 Mexico earthquake, NBS Build. Sci. Ser. 165 (1987) 207.

[41] D. Stanko, S. Markušić, S. Strelec, M. Gazdek, HVSR analysis of seismic site effects and soil-structure resonance in Varaždin city (North Croatia), Soil Dynam. Earthq. Eng. 92 (2017) 666-677.

[42] R.D. Borcherdt, Effects of local geology on ground motion near San Francisco Bay, Bull. Seismol. Soc. Am. 60 (1) (1970) 29-61.

[43] Y. Nakamura, A method for dynamic characteristics estimation of subsurface using microtremor on the ground surface. Railway Technical Research Institute, Quarterly Reports 30 (1) (1989).

[44] C. Zhu, F. Cotton, M. Pilz, Detecting site resonant frequency using HVSR: fourier versus response spectrum and the first versus the highest peak frequency, Bull. Seismol. Soc. Am. 110 (2) (2020) 427-440.

[45] K. Ishihara, Introduction to Dynamic Soil Mechanism, University of Tokyo, Tokyo, Japan, 1978.

[46] K. Tokimatsu, Y. Yoshimi, Empirical correlation of soil liquefaction based on SPT-N value and fines content, Soils Found. 23 (4) (1983) 56-74.

[47] K. Tokimatsu, S. Midorikawa, Y. Yoshii, Dynamic soil properties obtained from strong motion records, Proc. Twelfth Int. Conf. on Soil Mechanics and Foundation Engineering 3 (1989) 2015-2018.

[48] S. Midorikawa, H. Miura, Nonlinear behavior of soil observed in strong motion records from recent Japanese earthquakes, in: 14th World Conference on Earthquake Engineering, October 12-17, Beijing China, 2008.

[49] Y. Nakamura, November). Seismic vulnerability indices for ground and structures using microtremor, in: World Congress on Railway Research in Florence, Italy, 1997.

[50] J. Chandra, P. Gueguen, L.F. Bonilla, Application of PGV/vs proxy to asses nonlinear soil response : from dynamic centrifuge testing to Japanese K-net and kik-net data, in: 2nd. European Conference on Earthquake Engineering and Seismology, İstanbul, 25-29 August, 2014, pp. 1-8.

[51] J. Chandra, P. Gueguen, L.F. Bonilla, PGA-PGV/Vs considered as a stress-strain proxy for predicting nonlinear soil response, Soil Dynam. Earthq. Eng. 85 (2016) $146-160$.

[52] J.S. Markham, J.D. Bray, J.D. Macedo, R. Lique, Evaluating nonlinear effective stress site response analyses using records from the Canterbury earthquake sequence, Soil Dynam. Earthq. Eng. 82 (2016) 84-98.

[53] P. Gueguen, F. Bonilla, J. Douglas, Comparison of Nonlinearity (in-situ stress strain relation and G/Gmax reduction) observed in strong motion data bases and modelled in ground motion prediction equations, Civ. Environ. Eng. 109 (1) (2018) $178-186$. 